\title{
A comparative analysis of passive constructions in English, Afrikaans and isiXhosa: Grammar and acquisition
}

\author{
Anneke Perold Potgieter \\ Department of Sociology and Social Anthropology, Stellenbosch University, South Africa \\ E-mail: annekep@sun.ac.za
}

\begin{abstract}
Whilst literature on the acquisition of passive constructions by speakers of European languages abounds, there is a dearth of grammatical descriptions of passive constructions in (especially South) African languages that may serve as a basis for acquisition studies. Furthermore, the majority of studies have focused on monolingual participants only, leaving the typical multilingual African language acquisition context underrepresented. This paper addresses these gaps in the literature by offering an in-depth cross-linguistic comparison of passive constructions in the three official languages of the Western Cape, a province in South Africa, namely the Germanic languages English and Afrikaans and the Southern Bantu language isiXhosa. The grammatical description of passives in these languages covers the nature of the passive verb complex; the placement of the object and, in long passives, subject arguments; movement of the object argument across clause boundaries in infinitival clauses; existential passive constructions; case assignment; restrictions on passivisation; and verbal versus adjectival passive constructions. This information may serve as basis for finer syntactic analyses, studies of cross-linguistic bootstrapping, and also descriptive grammars. The paper finally presents normative data for the acquisition of passive constructions by monolingual speakers of English and by speakers of languages closely related to Afrikaans and isiXhosa (such data not yet being readily available for the latter two languages). The reported higher frequency of passive constructions in Bantu languages is cited as a possible explanation for the relatively early acquisition of this otherwise notoriously late-acquired construction.
\end{abstract}

Keywords: acquisition, Afrikaans, English, isiXhosa, passive constructions

\section{Introduction}

According to Deen (2011:155), the passive voice is "arguably the most well-studied phenomenon in all of child language [research]". This widespread scholarly interest is largely due to the general delay in the acquisition of passives across languages. The majority of the acquisition literature on this topic, however, is limited to European languages and monolingual participants. There is a dearth of grammatical descriptions of passive constructions in (especially South) African languages that may serve as a basis for acquisition studies. The multilingual contexts in which the majority of African children undergo language 
acquisition are also largely underrepresented in the literature. As such, this paper aims to offer an in-depth cross-linguistic comparison of passive constructions in the three official languages of the Western Cape, a province in South Africa, namely English, Afrikaans and isiXhosa. The paper furthermore presents normative data for the acquisition of passive constructions by monolingual speakers of English and of languages closely related to Afrikaans and isiXhosa (such data not yet being readily available for the latter two languages). The aim is to provide a grammatical basis for future studies on the acquisition of passives among multilingual speakers. (Cf. for example Potgieter's (2016) study of early trilingual isiXhosa-English-Afrikaans learners.)

At first glance, there seems to be little semantic difference between the active and passive voice, which calls into question the purpose of the passive construction. Various factors determining the use of the passive construction have been identified in the literature. For instance, the use of the passive (i) allows the object argument (typically the THEME/PATIENT argument) of the verb to surface as the sentence topic in the structural subject position, thereby indicating the perspective of the speaker; (ii) places emphasis on a "heavy/lengthy" AGENT argument through the use of a long passive, i.e. presenting it as the complement of a preposition (e.g. by in English and deur in Afrikaans); or (iii) allows the AGENT argument to be (deliberately) left unspecified through the use of a short/agentless passive (cf. for example Stein 1979; Ponelis 1989:324-326; Baratta 2009). With these functions of passive constructions as background, this paper provides a description of the grammar of passive constructions in, respectively, English (Section 2), Afrikaans (Section 3) and isiXhosa (Section 4), with points of similarity and difference being noted throughout. The description is non-formalistic in the sense that it is presented in a predominantly theoryneutral manner rather than within a particular theoretical framework. The paper concludes with a brief overview of the literature on the acquisition of passives by child learners of English, Afrikaans and isiXhosa, and/or closely related languages (Section 5).

\section{Passive constructions in English}

\subsection{Morphosyntactic structure}

Consider the sentence pairs in (1)-(5) below. The (a)-sentences represent typical passive constructions in English; the (b)-sentences represent the active counterparts of the respective passives.

(1) a. The baby is (being) rocked (by Mary).

b. Mary is rocking the baby.

(2) a. John was knocked over (by the car).

b. The car knocked over John.

(3) a. The schoolchildren were recognised (by Mr Petersen).

b. Mr Petersen recognised the school children.

(4) a. [When John arrived home yesterday,] the cake had been eaten (by Fido).

b. [When John arrived home yesterday,] Fido had eaten the cake. 

a. [Granny Paddy would like] the clothes to be washed (by Mary).
b. [Granny Paddy would like] Mary to wash the clothes.

As illustrated in each of the (a)-sentences above, the main verb (rocked, knocked over, recognised, eaten, washed) is in the form of a passive participle, i.e. a non-finite verb which encodes passive voice (Radford 2009:471). The passive participle (or passive verb, for short) is derived by attaching a passive morpheme in the form of the -ed or $-(e) n$ suffix to the verb stem (Ouhalla 1999:170). Whilst all regular verbs and many irregular verbs take the -ed ending, the passive participle form of many irregular verbs is derived by either (i) adding -en (or $-n$ ) to the verb stem, as in eaten and shown; (ii) changing the middle vowel, as in rung; or (iii) combining these two means, as in gotten (McArthur 1992:751-752). In English, the passive participle form of a verb is generally homophonous with the past perfect participle form of that verb (e.g. dropped, eaten, seen, stolen, taken, shown, etc.). Verbs that take the -ed suffix in their simple past tense form (e.g. dropped, chewed, listened), as well as certain irregular forms (e.g. taught, hurt, sought) are also homophonous with the passive participle form.

The passive construction additionally requires the presence of a free morpheme in the form of the passive voice auxiliary BE. ${ }^{1}$ This auxiliary can take various forms: $i$ s (denoting present tense, as in (1a)), was/were (denoting past tense, as in (2a) and (3a)), been (denoting perfect aspect, as in (4a)), or be (denoting a lack of tense in passive infinitival clauses, as in (5a)). Note that the perfect form of the passive auxiliary (i.e. been in (4a)) is obligatorily preceded by the aspectual auxiliary HAVE ((to) have, has, had, having), which serves to express past tense. $^{2}$

Sometimes, the passive auxiliary BE is substituted with GET (get, got, gotten). ${ }^{3}$ GET-passives are largely limited to informal registers and even then are infrequent compared to the more common BE-passive (Quirk, Greenbaum, Leech, Swartvik and Crystal 1985:161). GET is much more commonly employed as a "resulting copula" in what Quirk et al. (1985:161) term a "pseudo-passive" construction; the latter resembles a passive, but cannot express an AGENT, e.g. My mother is getting old (Quirk et al. 1985:161). However, if a GET-passive is indeed used, it will most often not contain an overt expression functioning as an animate AGENT (Quirk et al. 1985:161). Example (6a) below, when considered without the optional by-phrase, thus illustrates the most commonly occurring type of GET-passive. The fact that the AGENT in (6a) is animate is evident from the by-phrase, but even if this phrase were to be omitted, the implied AGENT would still clearly be animate. However, if the by-phrase in (6b) containing an inanimate AGENT were to be omitted, the verb does not imply that the AGENT is necessarily inanimate.

\footnotetext{
${ }^{1}$ Where BE represents the uninflected form of the auxiliary.

2 The rule regarding the obligatory presence of the aspectual auxiliary HAVE in the case of perfective passive constructions does not apply to present tense passive constructions. In the latter case, the presence of the progressive aspectual auxiliary "being" is optional (cf. (1a)). Note that the aspectual auxiliary "being" follows the passive auxiliary, whereas the aspectual auxiliary HAVE precedes the passive auxiliary.

${ }^{3}$ It is not clear whether GET (when used in place of the passive auxiliary BE) should also be analysed as an auxiliary or rather as some other type of verb. It does not seem to qualify as an auxiliary when measured against most of the syntactic criteria for this grammatical category (Quirk, Greenbaum, Leech, Swartvik and Crystal 1985:160). For analyses of so-called GET-passives, cf. for example Alexiadou (2005), Brownlow (2011), Butler and Tsoulas (2006), Embick (2004) and Hoekstra (1984).
} 

a. John got beaten up at school (by the bullies from sixth grade).
b. John got knocked over (by the car).

In both BE- and GET-passives, emphasis is placed on the expression occupying the structural subject position (John in the above examples) rather than on the AGENT. A distinguishing feature of GET-passives, however, is that emphasis is also placed on the usually negative effect that the action has on the entity denoted by the expression in the structural subject position (Quirk et al. 1985:161). According to Quirk et al. (1985:161), the emphasis on the unfavourable condition of the subject may account for the fact that GET-passives often have an unspecified AGENT and convey a negative attitude towards the action. ${ }^{4}$ Consider the following example, which refers back to the situation depicted in (4) above. Here, the implication is that the cake should have been stored in a safe place.

How did the cake get eaten before the party?

As illustrated in (1a)-(6a), an English passive sentence may optionally contain a by-phrase, where the complement of the preposition by thematically corresponds to the expression functioning as the subject in the active counterpart of the sentence. For instance, in (1a) the AGENT argument Mary is represented by the complement of by, whereas in (1b) this argument is represented by the subject of the sentence. Passives containing a by-phrase are often referred to as "long" or "agentive" passives, as opposed to "short" or "agentless" passives where the AGENT is unspecified through the omission of this phrase. ${ }^{5}$ According to Svartvik's (1966) analysis of corpus data, four out of every five English passive sentences are short passives.

As a general rule, the expression functioning as the object argument of the passive verb occupies the (clause-initial) structural subject position in passive constructions. ${ }^{6}$ This is illustrated by the examples in (1a)-(6a), where the object occurs preverbally. In addition, English also allows passive constructions in which the object argument remains in its original postverbal position, as in ( $8 \mathrm{~b})$ below. This possibility is, however, restricted to constructions

\footnotetext{
${ }^{4}$ Some languages - for example Japanese, Taiwanese and Sesotho - contain passive constructions which seem to be similar to GET-passives, where the subject is interpreted as being negatively affected in some way. These constructions are referred to as "adversity constructions" by Crawford (2012:23).

${ }^{5}$ Note that arguments with thematic roles other than that of AGENT may also occur as the complement of " $b y$ in long passives. According to Alexiadou and Anagnostopoulou (2007:2), the argument in the by-phrase of an English passive sentence can be either an AGENT (e.g. John in (ia) below), CAUSER (i.e. a natural force such as the storm in (ia)), INSTRUMENT (e.g. a stone in (ia)), or CAUSING EVENT (e.g. Will's banging in (ib)).

a. The window was broken by John/by the storm/with a stone.

b. The window was shattered by Will's banging.

It could be argued that a fifth thematic role, EXPERIENCER, may also be expressed by the complement of by in long passives, as in the example in (3a) above.

${ }^{6}$ By "object argument" is meant an expression that is selected by a verb/preposition from which it receives its specific thematic role. Within the framework of Government and Binding (GB) theory, the object argument is generally referred to as the "internal argument" of the verb (or preposition) and the subject argument as the "external argument" of the verb. The object argument typically receives the thematic role of THEME or PATIENT from the selecting verb/preposition, whereas the subject argument typically receives the thematic role of AGENT or EXPERIENCER (cf. Haegeman 1994:180-182). Within minimalist syntax, the (clause-initial) structural subject position is the specifier position of the functional category T(ense) (cf. for example Adger 2003:229), or I(inflection) in earlier versions of generative syntactic theory.
} 
where the object argument is an indefinite expression (Radford 2009:256). In such cases, the structural subject position is filled by the expletive (i.e. existential) pronoun there, which does not receive any thematic role.

a. No evidence of any corruption was found.

b. There was found no evidence of any corruption.

Radford (2009:256)

The sentences in (1a)-(6a) and in (8a) all represent main clauses, with the object argument of the passive participle surfacing in the structural subject position. Consider by contrast the examples in (9), which contain a main clause and an infinitival clause. In (9a), the expression occurring in the structural subject position of the main clause (i.e. many books) represents the object argument of the passive participle of the infinitival clause (i.e. stolen), rather than the passive participle of the main clause (i.e. believed). Clearly, then, in the case of infinitival clauses, the object argument of a passive participle can be moved across a clausal boundary. In the event that the object argument is not fronted, the structural subject position of the main clause is filled by the expletive there as in (9b) (although some speakers seem to find such examples only marginally acceptable).

a. Many books are believed to have been stolen.

b. ?There are believed to have been stolen many books.

With regard to case assignment, the nominal expression occurring in the complement position of the main verb in an active sentence (i.e. the object argument of the verb) receives accusative case. In (non-existential) passive sentences, in contrast, the object argument surfaces in the clause-initial structural subject position where, in tensed clauses, it displays nominative case. To illustrate, consider the examples below in which the form of the pronoun representing the object argument signals its case value. In the active sentence in (10a), her has accusative case, and in the passive sentence in (10b), she has nominative case.

(10) a. Grandpa Peter scolded her for coming home after dark.

b. She was scolded (by Grandpa Peter) for coming home after dark.

Note, however, that the object argument receives accusative case in the structural subject position of non-finite subordinate passive clauses. This is shown by the examples in (11): in both the non-finite active clause in (11a) and the corresponding non-finite passive clause in (11b), the pronoun representing the object argument has accusative case.

a. [Grandpa Peter believed] robbers to have attacked her on the way home.

b. [Grandpa Peter believed] her to have been attacked (by robbers) on the way home.

As regards the case value of the prepositional object in long passives (typically, the AGENT), this expression receives accusative case from the preposition by (cf. (12a) below). In the corresponding active sentence, this expression surfaces in the derived subject position with nominative case, as is shown in (12b).

(12) a. Debbie was scolded by him for coming home after dark.

b. He scolded Debbie for coming home after dark. 


\subsection{Restrictions on passivisation}

Not all English verbs can undergo passivisation. According to Pinker (1989:136), the broad generalisation is that only transitive verbs may undergo passivisation, provided they have both an AGENT and THEME/PATIENT argument. Crawford (2012:18), however, notes that this claim does not hold for verbs such as see, which are transitive, but non-actional, i.e. they do not award a thematic role of AGENT to the subject argument. ${ }^{7}$

Transitive verbs that select more than one object (i.e. ditransitive verbs) can generally undergo passivisation, although languages vary as to whether both the direct and indirect object (typically the BENEFACTIVE and THEME) or only a specific one of them may surface in the structural subject position in a passive construction (Crawford 2012:28). English is an example of a language with asymmetric passives, i.e. a language in which only the direct object (typically the BENEFACTIVE) may surface in the structural subject position of a passive construction (Crawford 2012:28,30). ${ }^{8}$ Consider the examples in (13).
a. I sent Pat a letter.
b. Pat was sent a letter.
c. *A letter was sent Pat.

Crawford (2012:31)

Based on Pinker's (1989:136) claim above that only transitive verbs may conditionally undergo passivisation, one can infer that intransitive verbs conversely may not undergo passivisation. According to Crawford (2012:19), English does not allow unergative or unaccusative verbs ${ }^{9}$ to passivise, as illustrated by the ungrammaticality of (14) below.

\footnotetext{
${ }^{7}$ According to Quirk et al. (1985:746), it is likely that non-actional verbs - including perception verbs such as see and hear and cognitive/emotive verbs such as feel and dream (generally referred to as psychological verbs) assign the thematic role of EXPERIENCER (or THEME; cf. for example Thatcher, Branigan, Mclean and Sorace 2008:196).

${ }^{8}$ Crawford (2012:30) notes that some speakers of English find THEME subjects in passive constructions acceptable, although this judgement is typically restricted to verb phrases containing give, and to a lesser extent to cases where the indirect object is a pronoun. Consider her examples below containing give:
}

a. He was given a watch.

b. A watch was given him.

\footnotetext{
${ }^{9}$ Unergative verbs are verbs that do not take a direct object argument (hence, are intransitive), and award the thematic role of AGENT (or EXPERIENCER) to their subject; cf. He might protest (Radford 2009:354). Ergative verbs, in contrast, are transitive in the sense that they take an object argument; however, although such verbs assign a THEME role to their direct object, the latter surfaces in the structural subject position (the reason being that the verb cannot assign case, i.e. it is unaccusative). For example, broke in The window broke functions as an ergative verb (cf. for example Radford 2009:455-456). Unaccusative verbs include ergative verbs, passive verbs and verbs of movement and (change of) state such as arise, occur, remain, come and arrive (as in (14b)). With unaccusative verbs, what seems to be the subject actually originates as the complement of the verb; cf. Several complications have arisen and the corresponding expletive construction There have arisen several complications (Radford 2009:249,483). In the latter example, the argument several complications remains in situ as the complement of the verb. As the name suggests, unaccusative verbs do not assign accusative case; rather, the object argument surfaces with nominative case (Radford 2009:250). In contrast to unergative verbs, which assign the thematic role of AGENT to their subject, unaccusative verbs assign the thematic role of THEME to their complement, which surfaces as the subject (Radford 2009:251).
} 
(14) a. *Mary was laughed.

b. *The chief was arrived by visitors.

The aspectual properties of a verb further determine whether it may undergo passivisation. According to Chomsky (as cited in Crawford 2012:18), English transitive stative verbs like cost, weigh and possessive have may not undergo passivisation. This is illustrated by the ungrammaticality of the passive sentences in (15) below.

(15) a. *Twenty rand is costed by the movie ticket.

b. *Five kilograms are weighed by the onions.

c. *A headache was had by me.

\subsection{Verbal versus adjectival passives}

An important distinction relevant to the semantics of passive constructions is that between verbal and adjectival passives and the related distinction between eventive and stative readings. The passive constructions that have been discussed above are all of the type that Deen (2011:158) considers "true verbal passives", which have clear active counterparts; adjectival passives, in contrast, "look deceptively like [short] passives, but are not true verbal passives". Consider the example below which may be interpreted as either a verbal or an adjectival passive.

(16) The door was broken.

Deen $(2011: 158)$

If (16) is regarded as a (short) verbal passive, broken serves as a passive participle with its object argument the door having been raised into the structural subject position (Deen 2011:158). This verbal passive is interpreted as a description of an event - someone broke the door. Conversely, if (16) is interpreted as an adjectival passive, broken is an adjectival participle and the door, serving as the logical subject of the sentence, originated in the subject position rather than being raised to it (Deen 2011:158). This adjectival passive is interpreted as a description of a state - the door is in a state of having been broken. Accordingly, verbal passives typically have what is called an "event reading", and adjectival passives typically have what is called a "state reading" (Crawford 2012:21).

As is evident from the example in (16), verbal and adjectival passives are homophonous in English, which may cause ambiguity in interpretation. As Conradie (1969:55) points out, this type of ambiguity may be irrelevant to the hearer/reader in certain contexts, but in other contexts it may be of importance to know whether the speaker/writer is simply describing a state or implicating someone in a given action. This ambiguity can be avoided by using GET rather than BE (Quirk et al. 1985:162). For instance, rephrasing (16) as The door got broken allows for only a verbal (i.e. event) reading. 


\section{Passive constructions in Afrikaans}

\subsection{Morphosyntactic structure}

Afrikaans is an indigenous South African language with strong West Germanic roots, specifically in $16^{\text {th }}$ century Dutch. The inflectional system of its parent having largely fallen away, Afrikaans is extremely impoverished on a morphological level. The only remnants of overt (verbal) inflection are to be found in the case of (i) the specific past, present and future tense forms of the verb hê ("have") and the auxiliary wees ("be"), none of these forms being marked for person, number or gender; and (ii) the prefix $g e-$, which serves to introduce both the past and the passive participle (Biberauer 2002:20-21). Consider the sentence pairs in (17)-(20) below. The (a)-sentences illustrate the typical structure of an Afrikaans passive sentence; the (b)-sentences represent the active counterparts of the respective passives.

(17) a. Die koek word (deur Fido) geëet.

the cake is-being (by Fido) eaten

"The cake is being eaten (by Fido)"

b. Fido eet die koek.

Fido eats the cake

"Fido eats the cake"

(18) a. [Die storieboek blyk] gelees te word (deur die kinders).

[the storybook seems] read to be (by the children)

"The storybook seems to be read (by the children)"

b. [Die kinders blyk] die storieboek te lees.

[the children seem] the storybook to read

"The children seem to read the storybook"

(19) a. Die klere is (deur Mary) gewas.

the clothes BE-past (by Mary) washed

"The clothes were washed (by Mary)"

b. Mary het die klere gewas.

Mary has the clothes washed

"Mary washed the clothes"

(20) a. [Toe John gister by die huis aangekom het,] was die bank [when John yesterday at the house arrived has,] BE-perfect the couch reeds (deur die honde) stukkend gekou. already (by the dogs) broken chewed "When John arrived home yesterday, the couch had already been badly chewed on (by the dogs)" 
b. [Toe John gister bydie huis aangekom het,] het die honde die bank [when John yesterday at the house arrived has,] have the dogs the couch reeds stukkend gekou.

already broken chewed

"When John arrived home yesterday, the dogs had already chewed badly on the couch"

The Afrikaans passive verbal sequence contains, at the very least, a distinct passive participle and a free morpheme in the form of a passive auxiliary. As in English, the Afrikaans passive participle is a non-finite verb that serves to encode the passive voice. In the case of regular verbs, this participle is derived by attaching a passive morpheme in the form of the prefix $g e$ to the verb stem, as mentioned above. ${ }^{10}$ In the (a)-sentences above, the main verbs geëet, gelees, gewas and gekou are all in the passive participle form.

Similar to the case of BE in English, the Afrikaans passive auxiliary is phonetically realised as some form of WEES ("be"). This auxiliary can take one of four forms. Firstly, the form word is used to denote both present tense and progressive aspect as in (17a); this is in contrast to English, where two distinct auxiliaries are required to express tense and aspect (cf. Section 2.1). Secondly, as with wees in (21) below, the form word is also used to denote a lack of tense in passive infinitival clauses, as in (18a). ${ }^{11}$ Thirdly, the form is is used to denote past tense, as in (19a). Lastly, the form was serves to denote both past tense and perfect aspect, as in (20a). ${ }^{12}$ Note that unlike in English where the perfect form of the passive auxiliary (i.e. been) is obligatorily preceded by the aspectual auxiliary HAVE, the Afrikaans perfective passive auxiliary was usually occurs on its own, independent of an aspectual auxiliary.

[Die gereg blyk] (deur haar man) gemaak te wees.

[the dish seems] (by her husband) made to be

"The dish seems to be made (by her husband)"

Afrikaans and English are largely similar in their use of a passive affix in the marking of the passive participle and the use of a free morpheme as passive auxiliary. As noted in Section

\footnotetext{
${ }^{10}$ Note that, similar to past participles, irregular passive verbs starting with the prefixes be-, ge-, her-, er-, ont- or ver- do not take the prefix ge-. Cf. Taalkommissie van die Suid-Afrikaanse Akademie vir Wetenskap en Kuns (2009:162-166) for the morphological and prosodic conditions under which the addition of $g e$ - is allowed, prohibited or optional.

${ }^{11}$ When used to express a lack of tense in passive infinitival clauses, wees is associated with a state reading and word with an event reading; cf. Section 3.3 below.

12 According to Ponelis (1979:267), the use of was is more common in formal writing than in colloquial speech, in which case is is preferred; in such cases the past perfect interpretation is dependent on the particular context. In some varieties of Afrikaans, the passive auxiliary was is used only to express the past tense in passive sentences, with the perfect aspect being expressed by the auxiliary WEES in its participial form, i.e. gewees, as shown in (i). In this case, the Afrikaans passive auxiliary was precedes the aspectual auxiliary gewees; this is in contrast to English, which shows the reverse order, as in (ii). The passive auxiliaries in the examples below are italicised and the aspectual auxiliaries bolded.
}

(i) [Toe John gister by die huis aangekom het,] was die bank reeds (deur die honde) stukkend gekou gewees. [when John yesterday at the house arrived has,] was the couch already (by the dogs) broken chewed been "When John arrived home yesterday, the couch had already been badly chewed on (by the dogs)"

(ii) [When John arrived home yesterday,] the cake had been eaten (by Fido). 
2.1, in English the passive participle form of a regular verb is generally homophonous with the past perfect participle form of that verb. The same applies to verbs that take the -ed suffix in their simple past tense form, as well as certain irregular verb forms. These remarks hold for Afrikaans as well, with passive, past perfect and simple past participles all displaying the same form, i.e. prefixed with ge-, as shown in (22a-c), respectively.

a. Die koekies is (deur Ouma Paddy) gebak. the cookies were (by Grandma Paddy) baked "The cookies were baked (by Grandma Paddy)"

b. Teen gisteraand het Ouma Paddy reeds die koekies klaar gebak. by last-night has Grandma Paddy already the cookies finished baked "By last night, Grandma Paddy had already finished baking the cookies"

c. Ouma Paddy het die koekies gebak.

Grandma Paddy has the cookies baked

"Grandma Paddy baked the cookies"

As illustrated in (17a)-(20a), (21) and (22a), an Afrikaans passive sentence may optionally contain a deur-phrase, forming a long passive. As in the case of the English by-phrase, the complement of the preposition deur thematically corresponds to the expression functioning as the subject in the active counterpart of the sentence. For instance, in (17a) the AGENT argument Fido is represented by the complement of deur, whereas in (17b) this argument is represented by the subject. According to Ponelis (1989:323), the long passive is used much less frequently in Afrikaans than the short passive. Conradie (1969:6) goes so far as to state that the AGENT argument in a(n Afrikaans) passive construction is "typically and characteristically" not present, i.e. it is not the case that it may be optionally omitted, but rather optionally added. ${ }^{13}$ With regard to the frequency of long passives, Afrikaans is thus similar to English (cf. Section 2.1). Note, however, that whereas the English by-phrase has a fixed postverbal position, the Afrikaans deur-phrase may occur both preverbally and postverbally without any apparent effect on interpretation, as in the following examples: ${ }^{14}$

a. Die wasgoed word deur Maryopgehang.

the washing is-being by Mary up-hung

"The washing is being hung up by Mary"

b. Die wasgoed word opgehang deur Mary. the washing is-being up-hung by Mary

"The washing is being hung up by Mary"

As regards the positioning of the object argument in a passive sentence, Afrikaans is largely similar to English. As a general rule, the expression functioning as the object argument of a passive verb surfaces in the structural subject position, as illustrated by the examples in (17a)(20a) and (22a). Also, more commonly than in English, Afrikaans allows passive constructions in which the expression in the structural subject position is the thematically

\footnotetext{
${ }^{13}$ Cf. Ponelis (1979:414-415) for possible reasons regarding the preference for short passives over long passives.

${ }^{14}$ For a discussion of the general phenomenon involving preverbal and postverbal prepositional phrases in Afrikaans and related languages, cf. Biberauer (2003), Biberauer and Roberts (2006) and Oosthuizen (2013).
} 
empty expletive pronoun daar ("there"), provided the object argument is an indefinite expression (Ponelis 1979:23-25). This is illustrated in (24) below, where the indefinite expression serving as the object argument of the passive verb is italicised.

$$
\begin{aligned}
& \text { Daar is geen noemenswaardige vordering gemaak nie. } \\
& \text { there was no noteworthy progress made NEG } \\
& \text { "There was no noteworthy progress made" }
\end{aligned}
$$

Ponelis (1979:413)

In (17a)-(20a), (22a) and in (23), the object argument occurs preverbally in the structural subject position; in (24), the object argument is preceded by the passive auxiliary, but still occurs preverbally, i.e. before the passive participle. This is in contrast to English, where an indefinite object argument may occur either preverbally or postverbally (as in the case of there-constructions). On the assumption that Afrikaans is underlyingly a verb-final language, the Afrikaans [object argument]-[passive participle] surface order can be ascribed to the fact that the object initially occupies a preverbal position, thus ruling out the possibility of this expression surfacing in a postverbal position, as is evident from the ungrammaticality of (25d) below. ${ }^{15}$ The (b) and (d) sentences in (25) are the Afrikaans counterparts of (a) and (c); the object arguments are in bold print.

(25) a. No evidence of any corruption was found.

(preverbal)

b. Geen bewyse van enige korrupsie is gevind nie.

(preverbal)

no evidence of any corruption was found NEG

"No evidence of any corruption was found"

c. There was found no evidence of any corruption.

(postverbal)

d. *Daar is gevind geen bewyse van enige korrupsie nie.

(postverbal) there was found no evidence of any corruption NEG

The grammatical counterpart of the daar-construction in (25d) is given in (26) below. Here, as in (24) above, the object argument precedes the passive participle.

(26) Daar is geen bewyse van enige korrupsie gevind nie. there was no evidence of any corruption found NEG

"There was no evidence of any corruption found"

\footnotetext{
${ }^{15}$ There are two exceptions to this general rule. In subject-initial main clauses lacking an auxiliary, the object argument follows the verb, as in (ia). This ordering is also found in finite subordinate clauses that lack an overt complementiser, as in (ib).
}

(i) a. Jan lees die boek.

Jan reads the book

"Jan reads the book"

b. Ek weet Jan lees die boek.

I know Jan reads the book

"I know Jan reads the book" 
Turning to movement across clause boundaries, Afrikaans, like English, allows the object argument of a passive verb to be moved out of a subordinate infinitival passive clause. With the exception of examples (18), (20) and (21), the examples of (non-existential) Afrikaans passives discussed above all function as main clauses, with the object argument of the passive verb surfacing in the structural subject position. The example in (27), in contrast, contains a main clause and an infinitival clause (cf. (18a) and (21) for similar examples). The expression occurring in the structural subject position of the main clause represents the object argument of the passive verb of the infinitival clause (i.e. vertrou) rather than of the verb of the main clause (i.e. blyk).

$$
\begin{aligned}
& \text { Die onderwysers blyk [(deur die ouers) vertrou te word]. } \\
& \text { the teachers seem [(by the parents) trusted to be] } \\
& \text { "The teachers seem to be trusted (by the parents)" }
\end{aligned}
$$

As in English, the object argument of the infinitival clause can remain in its original position, with the structural subject position of the main clause being filled with an expletive pronoun (daar), as illustrated in (28).

$$
\begin{aligned}
& \text { Daar blyk [baie onderwysers (deur die ouers) vertrou te word]. } \\
& \text { there seem [many teachers (by the parents) trusted to be] } \\
& \text { "There seem to be many teachers trusted (by the parents)" }
\end{aligned}
$$

Afrikaans is similar to English with regard to case assignment in passive sentences. The object argument of an active verb receives accusative case; this same object argument, when surfacing in the clause-initial structural subject position of a tensed clause in a (nonexistential) passive sentence, displays nominative case. To illustrate, consider the examples below in which the form of the pronoun representing the object argument signals its case value (pronouns providing the only morphological reflection of case in Afrikaans). In the active sentence in (29a), hom has accusative case, and in the passive sentence in (29b), hy has nominative case.
a. Ouma Paddy versorg hom.
Grandma Paddy looks-after him
"Grandma Paddy looks after him"
b. Hyword deur Ouma Paddy versorg. he is-being by Grandma Paddy looked-after "He is (being) looked after by Grandma Paddy"

Note, however, that the object argument receives accusative case in the structural subject position of non-finite subordinate passive clauses. This is shown by the examples in (30): in both the non-finite active clause in (30a) and the corresponding non-finite passive clause in (30b), the pronoun representing the object argument has accusative case. ${ }^{16}$

\footnotetext{
${ }^{16}$ Note that om in (30) and (31), co-occurring with the infinitive marker te in infinitival clauses, is regarded as a non-finite complementiser. This is also the case in Dutch (cf. for example Zwart 1997:109-116).
} 
a. [Ek verkies] vir Ouma Paddy om hom te versorg.

[I prefer] for Grandma Paddy COMP him to look-after "I prefer for Grandma Paddy to look after him"

b. [Ek verkies] vir hom om versorg te word (deur Ouma Paddy). [I prefer] for him COMP look-after to be (by Grandma Paddy) "I prefer for him to be looked after (by Grandma Paddy)"

As regards the case value of the prepositional object in long passives (typically the AGENT), this expression receives accusative case from the preposition deur (cf. (31a) below). In the corresponding active sentence, this expression surfaces in the derived subject position with nominative case, as is shown in (31b).

a. Ouma Paddy is deur hom aangemoedig om die kind te versorg. Grandma Paddy was by him encouraged COMP the child to look-after "Grandma Paddy was encouraged by him to look after the child"

b. Hy het Ouma Paddyaangemoedig om die kind te versorg. he has Grandma Paddy encouraged COMP the child to look-after "He encouraged Grandma Paddy to look after the child"

\subsection{Restrictions on passivisation}

It was noted in Section 2.2 that not all English verbs can undergo passivisation. This holds for Afrikaans as well: the verb needs to be transitive, unless an expletive daar-construction is used (cf. below and also Section 3.1 above) ${ }^{17}$ In the case of sentences with a monotransitive verb (i.e. a verb taking a single object argument), the nature of the verb may sometimes render the object "inaccessible" and so make passivisation impossible or at best "difficult" (Ponelis 1979:420). According to Ponelis (1979:420), this is the case with monotransitive main verbs that co-occur with linking verbs (i.e. skakelwerkwoorde such as gaan ("go") and kom ("come")), as well as monotransitive perception verbs. Consider the examples below adapted from Ponelis (1979:420); the relevant verbs are italicised.

a. Hulle het die kinders gaan wegbring. /*Die kinders is gaan wegbring. they have the children go dropped-off / the children were go dropped-off "They went to drop off the children"

b. Hulle het die boeke gesit en lees. /*Die boeke is gesit en lees. they have the books sat and read / the books were sat and read "They sat and read the books"

c. Hulle het die radio hoor speel. / ?Die radio is hoor speel. they have the radio hear play / the radio was heard play "They heard the radio play"

\footnotetext{
${ }^{17} \mathrm{As}$ in English, the aspectual properties of Afrikaans verbs also play a role in determining whether they may be passivised. As is the case with their English counterparts, Afrikaans transitive stative verbs such as kos ("cost"), weeg ("weigh") and possessive het ("have") do not passivise.
} 
As for ditransitive verbs (i.e. verbs taking two object arguments), recall that English is an asymmetric language that, for most speakers, does not allow indirect objects (mostly THEMES) to surface as the subjects of passive constructions (cf. Section 2.2). Afrikaans, in contrast, is a symmetric language in that generally either the direct or indirect object may surface as the subject in a passive construction without impacting on meaning (Conradie 1969:73). Only in certain cases is there a preference for either the one or the other to occur in the subject position in passive sentences (Conradie 1969:74). Regardless of which object surfaces in the subject position, the other is said to be "retained" as object in the passive construction (Conradie 1969:73). Consider the examples below in which the case forms of the personal pronouns indicate whether they serve as subject or retained object in the respective passive constructions in (33b) and (33c) ${ }^{18}$ (Note that the examples in (33) do not lend themselves to fully idiomatic translations into English, with some native speakers finding such translations only marginally acceptable.)
a. Pieter gun
(aan) hom haar.

Pieter grants/allows (to) him her

"Pieter grants him her"

\section{b. Hyword haar gegun (deur Pieter).}

he is-being her granted/allowed (by Pieter)

"He is being granted her (by Pieter)"

\section{Sy word (aan) hom gegun (deur Pieter). \\ she is-being (to) him granted/allowed (by Pieter) \\ "She is being granted to him (by Pieter)"}

As mentioned above, intransitive verbs cannot undergo passivisation unless an expletive daar-construction is employed. For example, the ungrammatical sentence in (34a) below contains an intransitive verb in passive form, but without any expression in the structural subject position; this is in contrast to the grammatical sentence in (34b), where the subject position is thematically empty but filled with the expletive daar.
a. *Word geslaap (deur Pieter). is-being slept (by Pieter) there is-being slept (by Pieter) "Pieter is sleeping"
b. Daar word geslaap (deur Pieter).

\footnotetext{
18 The preposition aan ("to") in the (a) and (c) sentences serves to mark the indirect object argument. Without this preposition, these sentences are ambiguous with hom and haar, respectively, allowing both an indirect and a direct object reading. In (33b), the nominative form of the fronted pronoun cannot be preceded by aan; if this preposition is pied-piped along with the pronoun, the latter is assigned accusative case, as in (i). It should be noted, though, that many speakers find such sentences at most marginally acceptable. Cf. Oosthuizen (2013:83:91) for an analysis of such ditransitive constructions in Afrikaans.
}

(i) 'Aan hom word haar gegun.

to him is-being her granted/allowed

"To him, she is being granted" 
Note that English does not allow the type of there-construction in (34b), as only transitive verbs may be passivised in English (cf. Section 2.2). Consider the ungrammaticality of (35) below.

*There is being slept (by Peter).

The class of Afrikaans intransitive verbs that may occur in a passive daar-construction is semantically restricted. Firstly, (ergative) unaccusative verbs such as gebeur ("happen") and vergaan ("perish/decay") do not passivise (Conradie 1969:82). To illustrate, consider the ungrammaticality of the following examples of a non-existential and existential passive construction containing an ergative unaccusative verb:

a. *Dinge word hier gebeur. $/ *$ Word (deur dinge) hier gebeur.
things are-being here happen / are-being (by things) here happen

b. *Daarword dinge hier gebeur. / *Daarword (deur dinge) hier gebeur. there are-being things here happen / there are-being (by things) here happen

A second semantic restriction on the class of verbs that may occur in a passive daarconstruction relates to the thematic role of the subject argument of the verb. Conradie (1969:81) states that generally only intransitive (specifically, unergative) verbs that express a deliberate human action (and therefore take an AGENT argument) are allowed in passive daar-constructions, e.g. bedel ("beg"), besluit ("decide") and bad ("bathe"). ${ }^{19}$ As regards the deliberateness of the action, Ponelis (1979:408-409) supports Conradie's claim in arguing that only actional verbs (handelingswerkwoorde, i.e. verbs that assign the AGENT role to the subject argument) may occur in Afrikaans daar-constructions. This is illustrated by the ungrammaticality of the passive sentence in (37b), where the verb is non-actional.

$$
\begin{aligned}
& \text { a. Die meisie lyk mooi. } \\
& \text { the girl looks pretty } \\
& \text { "The girl looks pretty" } \\
& \text { b. *Daar word mooi gelyk. } \\
& \text { there is-being pretty looked }
\end{aligned}
$$

(adapted from Ponelis 1979:409)

The above claim that only AGENT subject arguments can occur in passive daar-constructions is, however, too strong. In fact, some verbs that take an EXPERIENCER argument - e.g. psychological verbs such as droom ("dream"), bloos ("blush") and skrik ("become frightened"), and perception verbs such as sien ("see"), ruik ("smell") and hoor ("hear") - can also occur in passive daar-constructions. This is clear from the following examples:

a. Daar is groot geskrik(deur die kinders) toe hulle uitgevang is. there was big shocked (by the children) when they out-caught were "The children had a big scare when they were caught out"

\footnotetext{
19 Conradie (1969:82) further states that it is doubtful whether passive daar-constructions containing verbs expressing a deliberate animal action such as blaf ("bark"), runnik ("whinny/neigh") and blêr ("bleat") are grammatical. The accuracy of this statement, however, seems to be contentious.
} 
b. Daar is (deur die onderwysers) gesien hoe die kinders skelm rook. there was (by the teachers) saw how the children slyly smoke "The teachers saw the children smoking on the sly"

In summary, recall that, according to Crawford (2012:19), English does not allow unergative or unaccusative verbs to passivise under any circumstances (cf. Section 2.2). Afrikaans is largely similar, although this restriction can sometimes be overcome through the use of the existential daar-construction. Assuming, as argued above, that an AGENT argument is not a prerequisite for the derivation of an Afrikaans passive daar-construction, any unergative verb such as bedel ("beg"), lag ("laugh"), slaap ("sleep"), dink ("think") and skrik ("become frightened"; cf. (38a)) may be passivised in such a construction. Additionally, it seems that some unaccusative verbs of movement or (change of) state can also occur in Afrikaans passive daar-constructions, as illustrated in (39); it should be noted, though, that many speakers find such sentences only marginally acceptable.

a. ?Daar word (deur die gaste) gearriveer.

there is-being (by the guests) arrived

"The guests are arriving"

b. Daar is (deur die deelnemers) met die kompetisie begin. there was (by the participants) with the competition begin "The participants started with the competition"

\subsection{Verbal versus adjectival passives}

Consider next the ambiguity between event and state readings. It was pointed out in Section 2.3 that English verbal and adjectival passives are homophonous, which gives rise to the ambiguity in question. This type of ambiguity is also found in Afrikaans, albeit to a lesser extent. In Afrikaans passive constructions expressing the present progressive, the form of the passive auxiliary (i.e. word) unambiguously signals an event reading in which the action expressed by the verb is in progress. However, in the case of the passive auxiliary is, which indicates that the action expressed by the verb is completed, ambiguity does exist between an event and state reading, since a completed action may be said to closely resemble a state (Ponelis 1979:221). Consider (40) below. Two interpretations are possible: on the one hand a reading describing an action in the past ("someone bent his gun"), and on the other hand a reading describing a state in the present ("the gun is crooked") (Conradie 1969:53).

Sy geweer is gebuig.

his gun was/is bent

"His gun was bent" / "His gun is bent"

The same two interpretations illustrated in (40) are also found with the passive auxiliary was. For instance, (41) below allows for both an event and a state reading. On the event reading, was is interpreted as expressing the past perfect; on the state reading, it expresses the simple past tense (Conradie 1969:15,55). ${ }^{20}$

\footnotetext{
${ }^{20}$ The verbal expression occurring with is and was in sentences like (40) and (41), and which may be interpreted as either a participial adjective or as a passive participle, is referred to as a "potential participle" by Conradie (1969:15).
} 
Die huis was verkoop.

the house had-been/was sold

"The house had been sold" / "The house was sold"

Ponelis (1979:267), who claims that the use of the passive auxiliary form was is uncommon in colloquial speech, does not note any ambiguity relating to this auxiliary form. According to him, was usually signals an adjectival, active voice reading, whereas is evokes a verbal, passive voice reading.

\section{Passive constructions in isiXhosa}

\subsection{Morphosyntactic structure}

As a member of the Southern Bantu language family ${ }^{21}$, isiXhosa is typologically very different from Germanic languages such as English and Afrikaans. Like English, most Bantu languages display a basic subject-verb-object (SVO) word order as well as subject-verb agreement (Doke and Mofokeng 1985); this is in contrast to Afrikaans, which is underlyingly a subject-object-verb (SOV) language and which does not display any subject-verb agreement. As regards verbal morphology, however, Bantu languages differ significantly from both English and Afrikaans: typically, Bantu languages have very rich systems of agglutinating verbal morphology, compared to the relatively impoverished verbal morphology of English and especially Afrikaans. In all Bantu languages, nouns belong to specific noun classes, each indicated by a specific noun class prefix (or marker) (Demuth, Moloi and Machobane 2010:239). ${ }^{22}$ The particular class to which a noun belongs is further marked on the verb in the form of an agreement affix, the form of which is determined by the specific noun class prefix on the subject (Demuth et al. 2010:239). In Southern Bantu languages specifically, the verb complex is made up of a semantically meaningful stem, in combination with affixes that indicate grammatical characteristics and relationships such as subject and object agreement, tense-aspect, mood and negation; and various affixes such as the applicative and causative that serve to introduce further arguments (cf. for example Du Plessis and Visser 1992; Zeller 2008). To illustrate, consider the example of a simplex isiXhosa active sentence in (42) below. ${ }^{23}$ The prefix $u$ - on the subject $u J o h n$ indicates that this expression belongs to noun class $1 \mathrm{a}$; the specific subject-verb agreement marker, i.e. subject concord marker (SC), associated with nouns in this class (here, incidentally also $u$-) is

\footnotetext{
${ }^{21}$ The Southern Bantu family consists of the following four subgroups (Herbert and Bailey 2002):

(i) the Nguni group, i.e. isiXhosa, isiZulu, isiNdebele and SiSwati;

(ii) the Sotho-Tswana group; i.e. Sesotho sa Leboa (Northern Sotho), Sesotho (Southern Sotho) and Setswana;

(iii) the Tswa-Ronga group, i.e. Xitsonga (Shangaan), Ronga and Tswa; and

(iv) the Venda group, consisting of Tshivenda alone.

${ }^{22}$ In the literature, the isiXhosa noun class prefix itself is analysed as a morphologically complex unit, with the initial vowel in prefixes such as $u m$ - (class 1), $a b a$ - (class 2), imi- (class 4), etc. regarded as a "pre-prefix"; cf. for example Du Plessis (1978) and Du Plessis and Visser (1992). For the purposes of this paper, such pre-prefixes will not be indicated in the glosses given for the isiXhosa examples.

${ }^{23}$ The abbreviations used in the glosses are as follows: numeral = noun class and agreement; $1 \mathrm{SG} / 2 \mathrm{SG}=$ first/second person singular; $\mathrm{ADJ}=$ adjectival concord; CAUS = causative; $\mathrm{COP}=$ copula; $\mathrm{DEM}=$ demonstrative; LOC = locative; NEG = negative; NEUT = neutro-passive; OC $=$ object concord; PASS = passive; PAST = past tense; PRES = present tense; REL = relative (this marker entailing both a prefix and suffix); SC = subject concord. For a descriptive grammar of isiXhosa, cf. Oosthuysen (1958), Louw and Jubase (1963), Du Plessis and Visser (1992) and Munnik (2006).
} 
attached to the verb as a prefix. Similarly, the prefix izi- on the object izipho indicates noun class 8 , with the corresponding object-verb agreement marker, i.e. object concord marker (OC), of this class (i.e. - zi-) being attached to the verb. Note that the example in (42) displays the so-called "long form" of the present tense, indicated by the affix $-y a$ - that occurs between the SC and the OC (or, in cases where the OC is absent, between the SC and the verb stem).

$\begin{array}{ll}\text { UJohn uyazithenga } & \text { izipho. } \\ \text { u-John u-ya-zi-theng-a } & \text { izi-pho } \\ \text { 1a-John 1a.SC-PRES-8.OC-buy-PRES } & \text { 8-gifts } \\ \text { "John is buying gifts" } & \end{array}$

Note that whereas subject-verb agreement is mandatory in isiXhosa, the marking of objectverb agreement is largely optional (Saule, Moropa, Zililo and Hadebe 2007; Oosthuysen 1958:25). For example, if the object is represented by means of a full nominal expression, e.g. izipho ("gifts"), the OC can be omitted. If, however, the object is not represented by means of an overt nominal expression, the OC is obligatory, in which case the covert/implied object receives a pronominal reading. In the event that object-verb agreement is indeed marked, the relevant OC is attached immediately to the left of the verb stem, as seen in (42) (Oosthuysen 1958:26). If the SC consists of a vowel and a consonant, the corresponding OC takes the same form as the SC; if the SC consists of a vowel only, the corresponding OC takes the form of this same vowel preceded by a specific semi-vowel (e.g. $a$ - becomes $-w a$ - and $i$ - becomes $-y i$-) (Oosthuysen 1958:26). Moreover, in the case of noun classes 1 and 1a singular, the OC is - $m$ ("him"/"her"); and in the case of the object being second person singular in nature, the OC is $k u$ - ("you") (Oosthuysen 1958:26).

In isiXhosa, the passive voice is also expressed by means of a verbal affix. Consider the passive counterpart of (42) in (43) below:

$$
\begin{aligned}
& \text { Izipho ziyathengwa (nguJohn) } \\
& \text { izi-pho zi-ya-theng-w-a (ng-u-John) } \\
& \text { 8-gifts 8.SC-PRES-buy-PASS-PRES (1a.COP.24-1a-John) } \\
& \text { "Gifts are being bought (by John)" }
\end{aligned}
$$

The object of the active sentence in (42) has been raised into the structural subject position in the passive construction in (43). Here, the verb is in agreement with the noun class of the expression occupying the structural subject position, regardless of the thematic role of this expression - this is indicated by the SC $z i$-. As there is no expression occupying the structural object position in the passive sentence in (43), the verbal complex does not contain an OC. As for the subject argument of the active sentence in (42), this expression occurs in a copular noun phrase (i.e. nguJohn) in the passive sentence in (43).

As is evident from the example in (43), an isiXhosa sentence is marked as expressing the passive voice through the use of a bound morpheme that is attached to the verb stem. This affix commonly takes one of two forms: ${ }^{25}$ (i) $-i w$ - in the case of monosyllabic verb stems, as

\footnotetext{
${ }^{24}$ On the copula status of $n g$-, cf. Du Plessis and Visser (1992).

${ }^{25}$ Two other morpheme forms found with passive constructions in isiXhosa are -ek- and -akal-. The form -ek-is used when the expression representing the object argument is neutral (or unspecified) with regard to grammatical gender; Du Plessis and Visser (1992:71) refer to verbal complexes with this passive morpheme as "neutro-
} 
in (44a), and verb stems beginning with a latent $i$, as in (44b); or (ii) $-w$ - in the case of bisyllabic verb stems, as in (44c) (Louw and Jubase 1963:111). ${ }^{26}$
a. -tya
-tyiwa
"being eaten"
b. -(i)va
"hear"
-viwa
-bona
"see"
"being heard"

\section{-bonwa}
"being seen"

The addition of the passive affix $-w$ - to the verb stem results in various (morpho-)phonological changes. Firstly, a bilabial consonant occurring in the final syllable of a verb stem is palatalised (Louw and Jubase 1963:112; cf. also Du Plessis 1978:162). To illustrate, consider (45) below, which shows the specific changes that $m([\mathrm{~m}])$ and $p h\left(\left[\mathrm{p}^{\mathrm{h}}\right]\right)$ undergo in these conditions.

$$
\begin{array}{llll}
m \rightarrow n y \quad: & \begin{array}{l}
\text {-luma } \\
\text { "bite" }
\end{array} & \rightarrow & \begin{array}{l}
\text {-lunywa } \\
\text { "being bitten" }
\end{array} \\
p h \rightarrow t s h \quad: \quad \begin{array}{l}
\text {-bopha } \\
\text { "tie" }
\end{array} & \rightarrow \begin{array}{l}
\text {-botshwa } \\
\text { "being tied" }
\end{array}
\end{array}
$$

Du Plessis (1978:162)

Note that whilst the above changes still occur even if the relevant labial consonant is not immediately adjacent to the $-w$-, these changes do not apply to a labial consonant occurring in stem-initial position (Du Plessis 1978:162). The changes affecting $m$ and $p h$ under these conditions are illustrated in (46) below. In (46a), the labial consonant is separated from the passive affix by the causative affix -is-, and in (46b) by the applicative affix -el-.

$$
\begin{aligned}
& \text { a. } \quad \begin{array}{l}
\text {-lumisa } \\
\text { "let bite" }
\end{array} \\
& \text { b. } \quad \begin{array}{l}
\text {-lunyiswa } \\
\text { "let be bitten" }
\end{array} \\
& \text { "tie for" }
\end{aligned}
$$

Du Plessis (1978:162)

\footnotetext{
passive verbs". The less productive form -akal- is related to - $e k$ - in its neutro-passive meaning, the main difference being that $-e k$ - is used in cases where the object argument "came into a certain state of affairs or condition by itself, while in the case of -akal-it came into this condition through external factors" (Du Plessis and Visser 1992:74; cf. also Section 4.3 below).

${ }^{26}$ By "latent $i$-" is meant a phonetically unrealised vowel $i$ - whose effect is seen in certain vowel coalescence contexts (cf. Louw and Jubase 1963:76-77). Louw and Jubase (1963) seem to analyse the final vowel (FV) as forming part of the passive affix (i.e. $-i w \underline{a}$ and $-w \underline{a}$ ). In this paper, however, the general practice will be followed of analysing the passive affix sans the FV. The FV will furthermore be denoted as either "PRES" or "PAST" in the glosses, in order to indicate the tense it serves to express in the given example.
} 
Secondly, in the case of verb stems ending on $-m l$ - ([ml]) or $-m k-([\mathrm{mk}])$, these consonant clusters are replaced by -nyul- ([njœl]) and -nyuk- ([njœk]), respectively, when the passive -wis attached to the stem (Du Plessis 1978:162). This is illustrated in (47) below.
$\rightarrow$
"overwork" / "waste"
a. $\quad$ xhamla
-xhanyulwa
"being overworked" / "being wasted"
Du Plessis (1978:162)
b. -lumkela
"beware"
-lunyukelwa
"being beware"
Du Plessis (1978:162)

As seen above, isiXhosa is evidently similar to English and Afrikaans in that all three languages use an affix to mark the voice of the verb as passive. However, in contrast to the other two languages, isiXhosa does not indicate tense by means of a free morpheme in the form of a passive auxiliary (or, in some cases, the aspectual auxiliary HAVE in English; cf. Section 2.1). Whereas the main verb in English and Afrikaans tensed passive constructions takes the form of a non-finite passive participle, the agglutinating nature of isiXhosa verbal morphology renders the main verb finite in that tense is indicated by means of a specific affix on the verb itself. The affixes that mark the tense of passive isiXhosa verbs are generally the same ones found with active verbs. In the case of the perfective, however, distinct tense markers are used in the active and passive voice.

Tense is associated with a variety of verbal affixes in isiXhosa. Moreover, two general forms of tense indication are employed, namely a "long" and a "short" form. For example, the final vowel (FV) - $a$ marks the present tense. As touched on above in reference to example (42), in an expression denoting the present tense, the affix -ya- may be inserted between the SC and the OC (or, in cases where the OC is absent, between the SC and the verb stem). Such a construction is termed the "long form" of the present tense. Generally, -ya- is found with "unexpanded predicates", i.e. where the verb is not followed by an object, an adverbial expression, etc.; however, if the verb receives primary stress, it may occur with $-y a-$ irrespective of whether it is followed by any other expression (Louw and Jubase 1963:39). The "short form" of the present tense is found in cases where the verb is unstressed and is followed by some other expression such as an object or an adverb, this form being marked by the omission of $-y a$ - (Oosthuysen 1958:6-7). ${ }^{27}$ To indicate the perfect past tense, the FV is replaced by the affix -ile (in the long form) or $-e$ (in the short form). The affix $-a$ - may be inserted to the right of the SC to mark the remote completed past, also known as the "A-past" (this affix often replacing the final vowel of the SC). Furthermore, the suffix $-y a /-z a$ may be attached to the SC to mark the future tense, in conjunction with the prefix $(u) k u$ - that is attached to the verb in this case (Oosthuysen 1958:39-44). For a detailed description of tense indication in isiXhosa, cf. Oosthuysen (1958), Louw and Jubase (1963), Du Plessis (1978) and Du Plessis and Visser (1992).

Recall that the passive participle form of a regular verb is generally homophonous with the past perfect participle form of that verb in the case of both English and Afrikaans (and with the simple past participle form in the case of Afrikaans), this phenomenon often leading to ambiguity in interpretation (cf. Sections 2.1 and 3.1). This is not, however, the case in

\footnotetext{
${ }^{27}$ Cf. Du Plessis (1978:115-121) for a more detailed discussion of the specific grammatical contexts that govern the presence/absence of $-y a-$, as well as the possible semantic features that may be associated with, respectively, the long and short form of the present tense.
} 
isiXhosa. In this language, regular active verbs that are not followed by any other expression(s) such as an object or an adverb are marked as the long form of the perfective by substituting the FV - $a$ with -ile, as mentioned above (Louw and Jubase 1963:41; Du Plessis 1978:126). If the passive affix $-w$ - is added to such an active verb, the $-l$ - is omitted, so that the verb ends on -iwe (Louw and Jubase 1963:111). In the case of regular active verbs that are followed by one or more expressions, the short form of the perfective is used, i.e. the FV $-a$ is substituted with - $e$ (Louw and Jubase 1963:42; Du Plessis 1978:127). In the passivisation of this type of active verb, $-w$ - is infixed before the perfective $-e$, so that the verb ends on -we (Louw and Jubase 1963:111). Hence, ambiguity in interpretation is avoided by the clear (morpho-)phonological differences between the perfective form and the passive form of a verb. To illustrate, consider the following examples: (48a) illustrates the difference between the forms of the verb bona ("see") when used to express the long perfective in the active and passive voice, respectively; (48b) similarly illustrates the difference between the forms of this verb when used to express the short perfective in the two voices.

$\begin{array}{llll}\text { a. Active voice: } & \begin{array}{l}\text {-bonile } \\ \text { "had seen" }\end{array} & \text { Passive voice: } & \begin{array}{l}\text {-boniwe } \\ \text { "had been seen" }\end{array} \\ \text { b. Active voice: } & \begin{array}{l}\text {-bone } \\ \text { "had seen" }\end{array} & \text { Passive voice: } & \begin{array}{l}\text {-bonwe } \\ \text { "had been seen" }\end{array}\end{array}$

As illustrated in (43), isiXhosa allows for both long and short passives. In a long passive, the expression functioning as the subject in its active counterpart surfaces as the complement of the passive verb in the form of a copular noun phrase (Du Plessis and Visser 1992:81). This phrase is introduced by a copular prefix which serves the same semantic function as the English preposition by and the Afrikaans preposition deur in the context of passive sentences. The form of the copular prefix is determined by the class of the noun to which it attaches (Louw and Jubase 1963:106). ${ }^{28}$ As in the case of the English by-phrase and Afrikaans deurphrase, the argument in the copular noun phrase of an isiXhosa passive construction displays the same thematic role as that displayed by the argument in the subject position of the corresponding active sentence (Du Plessis and Visser 1992:81). For instance, in the active sentence in (42), the AGENT argument uJohn is represented by the subject, whereas in the passive counterpart of this sentence in (43), this same AGENT is the complement of the copula $n g$ - in the copular noun phrase. Note that, similar to the English by-phrase but in contrast to the Afrikaans deur-phrase, the isiXhosa copular noun phrase may only occur postverbally. The exact postverbal position in which this phrase occurs may, however, differ according to discourse factors (Du Plessis and Visser 1992:84).

\footnotetext{
${ }^{28}$ Munnik (2006:143-144) explicates three forms that are commonly displayed by the copular prefix:

(i) in the case of nouns from classes 1, 1a, 2, 2a, 3 and 6 (where the relevant class prefix starts with $u$ - or $a$-), the copular prefix is $n g$-, as in e.g. umntu (class 1 singular, "person"), which becomes ngumntu ("it is a person"); abantu (class 2 plural, "people"), which becomes ngabantu ("it is people"); and amahashe (class 6 plural, "horses"), which becomes ngamahashe ("it is horses");

(ii) in the case of nouns from classes 4 (plural) and 9 (singular), where the relevant prefix starts with $i$-, the semivowel $y$ - serves as the copular prefix, as in e.g. imithi (class 4, "trees"), which becomes yimithi ("it is trees"); and inkomo (class 9, "ox"), which becomes yinkomo ("it is an ox"); and

(iii) in all the remaining cases, the copular prefix attached to the noun is identical to the consonant that occurs in the relevant (verbal) SC, as in e.g. iintsana (class 10 plural, "babies", $\mathrm{SC}=z i-$ ), which becomes ziintsana ("it is babies").
} 
With regard to the positioning of the object argument in a passive sentence, isiXhosa is largely similar to English and Afrikaans. As a general rule, the expression functioning as the object argument of an isiXhosa passive verb surfaces preverbally in the structural subject position (Du Plessis and Visser 1992:72). Recall that the SC appended to the verb agrees with the nominal expression occurring in the structural subject position, irrespective of whether this expression functions as the subject or object argument of the verb. In other words, in the case of passive sentences, the SC on the verb agrees with the noun class prefix of the object argument that has been raised into the structural subject position. The preverbal positioning of this argument is evident in (43) above, where the object argument is izipho.

However, like English and Afrikaans, isiXhosa also allows passive constructions in which the structural subject position is thematically empty due to the object argument remaining in its original position (in English and isiXhosa, this is a postverbal position, both languages being underlyingly SVO). In this case, the passive verb takes the expletive prefix $k u$ - (Du Plessis and Visser 1992:70). ${ }^{29}$ In English and, as a general rule, also in Afrikaans, such expletive constructions are restricted to cases where the object argument is an indefinite expression. IsiXhosa, in contrast, allows both definite and indefinite expressions to serve as the object argument in expletive (passive) constructions. This is illustrated by the grammaticality of the sentence in (49), in which the italicised object argument is a definite expression occurring in its original postverbal position. Note that in isiXhosa, as in English and Afrikaans, the structural subject position is thematically empty. However, unlike in the other two languages, in isiXhosa this position is not filled by a free morpheme (such as thereldaar in English/Afrikaans), but is left phonetically empty, with subject-verb agreement being expressed by the SC $k u$ - that is attached to the verb. Underlyingly, however, the structural subject position in the isiXhosa construction at hand is filled by a phonetically empty existential pronominal element that is associated with $k u$ - (Du Plessis and Visser 1992:72). ${ }^{30}$
Kubhalwa
iincwadi (ngababhali).
ku-bhal-w-a
iin-cwadi (ng-aba-bhali)
15.SC-write-PASS-PRES 10-book (2.SC-2-writer)
"Books are being written (by writers)"

Not only may the object argument of a passive verb occupy either a preverbal or a postverbal position (as in $k u$-constructions), it may also be omitted. As pointed out by Du Plessis and Visser (1992:73), the $k u$-construction allows for a transitive passive verb to undergo "argument reduction". This means that the verb can be used without any expression occupying the available object argument position. For instance, the absence of such an expression in (50b) makes it unclear, if no context is supplied, who/what underwent the action expressed by the verb. In this regard, isiXhosa differs from both English and Afrikaans in that it allows impersonal expletive passive constructions where an obligatory transitive verb is

\footnotetext{
${ }^{29}$ According to Zeller (2008:224), the expletive affix in Bantu languages is a "non-agreeing default marker from a locative noun class" (e.g. class $17 \mathrm{ku}$ - in isiZulu and class $16 \mathrm{ha}$ - in Kinyarwanda); in isiXhosa this affix belongs to class 15 , and also takes the form $k u^{-}$. As this marker is attached to the verb in the SC slot in cases where non-raising of the predicate-internal subject argument would have resulted in this position being left empty, Zeller (2008:224) assumes that this marker serves a purely morphological purpose. In their description of expletive passive sentences, Du Plessis and Visser (1992) do not specifically characterise the isiXhosa expletive affix $k u$ - as belonging to a locative noun class; in their (1992:292) discussion of demonstratives they do, however, refer to $k u$ - as a "locative head".

${ }^{30}$ For (minimalist) generative analyses of the expletive construction in Bantu languages, cf. Zeller (2008).
} 
used without any object argument. This difference between the three languages is illustrated by the examples in (50). Note that some native speakers of Afrikaans may find such constructions grammatically acceptable in the case of psychological verbs such as gehaat ("hated"), but not in the case of actional verbs such as gered ("saved").
a. Kuthiywe
abantu. / Kusindiswe
ku-thiy-w-e
aba-ntu / ku-sind-is-w-e
15.SC-hate-PASS-PAST
"People were hated"
/ "People were saved"
b. Kuthiyiwe. / Kusindisiwe.
ku-thiy-i(w)e / ku-sind-is-i(w)e31
15.SC-hate-PAST(PASS) / 15.SC-save-CAUS-PAST(PASS)
"There was hated" / "There was saved"
c. $\quad *$ There was hated / saved.
d. Daar is ?gehaat/*gered.
there was hated / saved.

abantu.

aba-ntu

2-person / 15.SC-save-CAUS-PASS-PAST 2-person

In short, the object argument in an isiXhosa passive sentence may, as in English, occur either preverbally (in non-existential constructions) or postverbally (in $k u$-constructions, where the object argument may be a definite expression, unlike in English). This is in contrast to Afrikaans, which does not allow the object argument to occur in the postverbal position, not even in existential daar-constructions. Moreover, the object argument in an isiXhosa passive sentence may also be omitted altogether, unlike in English and Afrikaans.

According to Du Plessis and Visser (1992:70), passive constructions with $k u$ - are "quite general" in isiXhosa. In fact, it seems as if the expletive passive construction might be more frequently used in isiXhosa than in English and Afrikaans, for two reasons. Firstly, isiXhosa passive $k u$-constructions are not limited by the (in)definiteness of the object argument, as is the case in English and Afrikaans. Secondly, the negative counterparts of passive sentences introduced by $k u$ - are often used to express "prohibitions", as in (51) (Du Plessis and Visser 1992:71). The discussion of the expletive $k u$-construction is continued in Section 4.2.

(51) a. Akungenwa.

a-ku-ngen-w-a

NEG-15.SC-enter-PASS-PRES

"There is not being entered (no admittance)"

b. Akutshaywa.

a-ku-tshay-w-a

NEG-15.SC-smoke-PASS-PRES

"There is not being smoked (no smoking)"

\footnotetext{
${ }^{31}$ Here, the long form perfective marker -ile was changed as a result of the addition of the passive affix -w-, which replaces the $-l$ - (as discussed above). In the gloss, this complex morpheme is indicated as PAST(PASS).
} 
Let us now turn to movement across clause boundaries. Recall that, in the case of subordinate infinitival passive clauses, both English and Afrikaans allow the object argument of the passive verb to be moved out of the subordinate clause into the main clause. However, a direct comparison between English and Afrikaans on the one hand and isiXhosa on the other is not possible in this regard: isiXhosa does not employ a comparable construction type to express meanings conveyed by sentences such as (52a) below (Visser, personal communication, February 5, 2013). In the isiXhosa example in (52b), -ya- (the long form marker of the present tense, which also encodes aspectual properties) and the FV $-a$ both signal the present tense. IsiXhosa thus utilises a finite subordinate passive clause to express a similar meaning to that expressed by an infinitival subordinate passive clause in English and Afrikaans. No direct comparison can therefore be drawn here in terms of movement across clause boundaries.

(52) a. [The teachers seem] to be trusted (by the parents).
b. [Ootitshala ingathi] bayathenjwa
(ngabazali).
[oo-titshala ingathi] ba-ya-themb-w-a
(ng-aba-zali)
[2a-teachers as-if] 2a.SC-PRES-trust-PASS-PRES (2.COP-2-parents)
"The teachers seem to be trusted by the parents"

IsiXhosa seems to be similar to English and Afrikaans with regard to structural case assignment. Simplifying somewhat, the object argument is assigned accusative case by the verb in an active sentence; in a passive sentence, however, the passive verb lacks this ability to assign accusative case (Du Plessis and Visser 1992:72). ${ }^{32}$ Upon surfacing in the clauseinitial structural subject position of a tensed clause in a (non-existential) passive sentence, this same object argument receives the nominative case value; according to Du Plessis and Visser (1992:72), this case value is assigned by the SC on the passive verb. It was noted that, in the case of English and Afrikaans non-finite subordinate passive clauses, the object argument receives accusative case in the structural subject position. A direct comparison cannot be drawn in this regard between English and Afrikaans on the one hand and isiXhosa on the other, as the subordinate clause in a semantically comparable isiXhosa construction can only be finite, as opposed to non-finite (Visser, personal communication, February 5, 2013). Furthermore, whereas English and Afrikaans display overt case marking on certain pronouns, case is not marked overtly in isiXhosa. For this reason, illustrative examples cannot be provided here.

Recall that in a passive expletive $k u$-construction where the object argument is realised (cf. above), this argument does not surface in the structural subject position, but remains unraised in its original postverbal position. Here, the object argument cannot receive accusative case, as the passive verb has lost the ability to assign this case; instead, according to Du Plessis and Visser (1992:73), the object argument "occurs in a chain with $k u$ - to receive nominative case". ${ }^{33}$ Note that, as the object argument cannot acquire accusative case due to the nature of

\footnotetext{
${ }^{32}$ In terms of the proposals concerning case assignment within the framework of GB theory, the verbal passive morphology is said to "absorb" the accusative case; cf. for example Haegeman (1994:182-185) and, for isiXhosa, Du Plessis and Visser (1992:72).

${ }_{33}$ According to Du Plessis and Visser (1992:73), the structural subject position is filled by the covert pronominal element pro, which receives nominative case through being in agreement with the verb. They (1992:80) go on to state that it is actually pro that enters into a case-agreement relation with the object argument, rather than $\mathrm{ku}$ -
} 
the passive verb, it cannot occur in conjunction with an OC on the main verb (Du Plessis and Visser 1992:73). This is shown by the difference in grammaticality between the (a) and (b) sentences below (adapted from Du Plessis and Visser 1992:72-73).
a. Kukhiwe
umbona.
$\mathrm{proi}_{\mathrm{i}} \mathrm{ku}_{\mathrm{i}} \mathrm{-kh}-\mathrm{iw}-\mathrm{e}$
u-mbona
proi $15 . \mathrm{SC}_{\mathrm{i}}$-pluck-PASS-PAST 1a-mealie
"There were plucked mealies"
b. $\quad *$ Kuwukhiwe umbona (where $w u-=\mathrm{OC}$ )

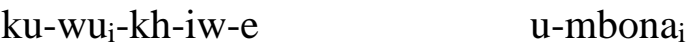
15.SC-15.OCi-pluck-PASS-PAST 1a-mealie $\mathrm{i}_{\mathrm{i}}$

Recall that in English and Afrikaans long passives, the argument in the by-/deur-phrase receives accusative case from the preceding preposition. In isiXhosa, the expression serving as the argument in the copular noun phrase present in long passives (typically, the AGENT) likely receives (abstract) accusative case from the copula (cf. (54a) below). In the corresponding active sentence, this argument surfaces in the derived subject position with nominative case assigned by the SC on the verb (cf. (54b)).

$\begin{array}{ll}\text { a. UDebbie ubethwe } & \text { nguye ngenxa yokufika sekumnyama. } \\ \text { u-Debbie u-beth-w-e } & \text { ng-(u)ye } \\ \text { 1a-Debbie } & \text { 1a.SC-beat-PASS-PAST } 1 / 1 \text { a.COP-1/1a.PRO(him/her) } \\ \text { (ngenxa ya-uku)34-fik-a } & \text { se-ku-mnyama } \\ \text { (because of-to)-arrive-PRES } & \text { already-15.COP-dark } \\ \text { "Debbie was beaten by him/her because she arrived when it was already dark" }\end{array}$

b. Ubethe uDebbie ngenxa yokufika sekumnyama.

u-beth-e u-Debbie (ngenxa ya-uku)-fik-a

2SG-beat-PAST 1a-Debbie (because of-to)-arrive-PRES

se-ku-mnyama

already-15.COP-dark

"He/she beat Debbie because it was already dark when she arrived"

\subsection{Restrictions on passivisation}

Like Afrikaans, isiXhosa allows both transitive and intransitive verbs to undergo passivisation, provided an expletive construction is used in the case of the latter verb type (which, in contrast, is not allowed to undergo passivisation in English). In the case of monotransitive verbs, the isiXhosa passive morphology has the effect of rendering the verb unaccusative. This is evident in $k u$-constructions: despite the object remaining in its postverbal position, the obligatory absence of the $\mathrm{OC}$ on the verb means that there is no overt morphological agreement between the verb and its object. If the OC is taken to be involved (either directly or indirectly) in the assignment of accusative case, its absence would account for the unaccusative nature of the verb. Hence, as suggested above, the object in such constructions is assigned nominative case by virtue of occurring in a chain with $k u$ - (cf. also

\footnotetext{
${ }^{34}$ Note that ngenxa yoku- is a set expression denoting cause or reason; in loose translation it equates to "because of'.
} 
Section 4.1). The obligatory absence of an OC in the construction under discussion is illustrated by the following example adapted from Du Plessis (1978:163):
a. Le ndoda ilima intsimi
le ndoda i-lim-a intsimi
9.DEM.this man 9.SC-plough-PRES land
"This man ploughs the land"
b. Kulinywa intsimi yile ndoda. $^{35}$
ku-lim-w-a intsimi yi-le ndoda
15.SC-plough-PASS-PRES land 9.COP-9.DEM.this man
"There is being ploughed a land by this man"
c. *Kuyilinywa
ku-yi-lim-w-a
(intsimi) yile
ndoda.
(intsimi) yi-le
ndoda
15.SC-9.oC-plough-PASS-PRES (land) 9.COP-9.DEM.this man

With regard to ditransitive verbs, isiXhosa, like Afrikaans, is a symmetric language in that either the direct or indirect object may surface in the structural subject position of a passive construction (Du Plessis 1978:164). For example, in (56b) the indirect object was raised and in (56c) the direct object, yet both express the same meaning; note that the verb complexes in these two sentences do not contain any OCs.
a. Ndinika
umntwana iilekese
ndi-nik-a
um-ntwana ii-lekese
1SG.SC-give-PRES 1-child 10-sweets
"I give the child sweets"
b. Umntwana unikwa iilekese ndim.
um-ntwana u-nik-w-a ii-lekese ndim
1-child 1.SC-give-PASS-PRES 10-sweets 1SG.COP
"The child is given sweets by me"
c. Iilekese zinikwa umntwana ndim.
ii-lekese zi-nik-w-a um-ntwana ndim
10-sweets 10. SC-give-PASS-PRES 1-child 1sG.COP
"Sweets are given the child by me"

Du Plessis (1978:164)

In sentences where the indirect object is raised (as in (56b)), the direct object can be omitted provided that the OC associated with it is appended to the verb, as illustrated in (57a) ${ }^{36} \mathrm{In}$ contrast, the indirect object cannot be omitted in sentences where the direct object is raised, as shown in (57b); cf. Du Plessis (1978:164) and Du Plessis and Visser (1992:77). Whereas isiXhosa allows the omission of the direct object under the circumstances described above,

\footnotetext{
${ }^{35}$ For the form of the passive morpheme, cf. Section 4.1.

${ }^{36}$ The optional dropping of the direct object is a general phenomenon in isiXhosa that is not limited to passive sentences. The direct object may thus be mentioned only once at the start of the discourse, with the associated $\mathrm{OC}$ on relevant verbs serving to indicate this specific object referent at later stages in the discourse.
} 
English and Afrikaans allow neither the direct nor the indirect object of a ditransitive verb to be omitted, regardless of which one is raised. This mandatory presence of both object arguments is evident in (57c-d).
a. Umntwana uzinikwa
ndim.
um-ntwana u-zi-nik-w-a ndim
1-child 1.SC-10.OC-give-PASS-PRES 1SG.COP.COP
"The child is given it by me"

$\begin{array}{lll}\text { *Umntwana } & \text { unikwa } & \text { ndim. } \\ \text { um-ntwana } & \text { u-nik-w-a } & \text { ndim } \\ \text { 1-child } & \text { 1.SC-give-PASS-PRES } & \text { 1SG.COP }\end{array}$

(adapted from Du Plessis 1978:164)

b. *Iilekese zimnikwa ndim.

ii-lekese zi-m-nik-w-a ndim

10-sweets 10.SC-1.OC-give-PASS-PRES 1SG.COP

(adapted from Du Plessis 1978:164)

c. Geluk is (aan)haar gegun.

happiness was (to) her granted/allowed

"Happiness was granted her"

*Geluk is (aan) gegun.

happiness was (to) granted/allowed

*Is (aan) haar gegun.

was (to) her granted/allowed

d. Peter was given an award. / *Peter was given. / *Was given an award.

Apart from mono- and ditransitive verbs, isiXhosa, like Afrikaans, also allows intransitive verbs to undergo passivisation, provided that they are used in an expletive construction, as in the isiXhosa example in (58a) below (Du Plessis 1978:163). However, such constructions are restricted in two ways: (i) in cases where the tense can normally be expressed by either a long or a short form, only the long form may be used; and (ii) the AGENT/EXPERIENCER which occurs in the copular noun phrase must be unspecified (i.e. non-specific) and usually also plural (Du Plessis and Visser 1992:82). ${ }^{37}$ These restrictions are evident from the ungrammaticality of (58b-d) below. The (b) sentence is ungrammatical because the short form of the present tense is employed (i.e. the form without the morpheme -ya-). In (58c-d) the long form is employed, but these sentences are nevertheless (at least marginally) ungrammatical, because in (c) the EXPERIENCER is singular and in (d) the EXPERIENCER is specified and singular.

\footnotetext{
${ }^{37}$ Du Plessis and Visser (1992:83) state that these restrictions seem to be partially applicable to $k u$-constructions containing transitive verbs as well, as the grammaticality of the latter type of construction is questionable when the AGENT/EXPERIENCER is in the first or second person (i.e. specified rather than unspecified).
} 

a. Kuyalilwa ngabantwana.
ku-ya-lil-w-a ng-aba-ntwana
"There is being cried by the children"
15.SC-PRES-cry-PASS-PRES 2.COP-2-children
b. *Kulilwa ngabantwana.
ku-lil-w-a ng-aba-ntwana
15.SC-cry-PASS-PRES 2.COP-2-children
c. ?Kuyalilwa ngumntwana.
ku-ya-lil-w-a ng-um-ntwana
15.SC-PRES-cry-PASS-PRES 1.COP-1-child
"There is being cried by a child"
d. *Kuyalilwa ndim.
ku-ya-lil-w-a ndim
15.SC-PRES-cry-PASS-PRES 1SG.COP

Recall that both English and Afrikaans exhibit, to different extents, a restriction on the class of intransitive verbs that may undergo passivisation. According to Crawford (2012:19), English does not allow unergative or unaccusative verbs to passivise under any circumstances (cf. Section 2.2). Afrikaans is largely similar, although this restriction can sometimes be overcome through the use of the existential daar-construction, allowing unergative verbs such as bedel ("beg"), lag ("laugh") and slaap ("sleep") and perhaps some unaccusative verbs of movement or (change of) state such as arriveer ("arrive") and begin ("begin") to be passivised in such a construction. As for isiXhosa, no such restrictions apply to the class of intransitive verbs that may undergo passivisation (Visser, personal communication, February $5,2013)$.

IsiXhosa does, however, share with English and Afrikaans two other restrictions relating to passivisation. Firstly, transitive stative verbs may not undergo passivisation. It should be noted, however, that a direct comparison in this regard between English and Afrikaans on the one hand and isiXhosa on the other is not possible: the categorical and structural realisations in isiXhosa of meanings expressed in English by stative verbs such as cost, weigh and possessive have differ, with adjectival predicate phrases, among others, being employed. Secondly, according to Visser (personal communication, February 5, 2013), isiXhosa weather verbs such as netha ("rain"), khithika ("snow"), duduma ("thunder") and -wa isichotho ("hail", literally "-falls hail") may not be passivised, not even in an existential construction. This is also the case in English and Afrikaans, as the ungrammatical examples in (59) show.

(59) a. *Kuyanethwa.

ku-ya-neth-w-a

15.SC-PRES-rain-PASS-PRES

*Kuyadudunjwa.

ku-ya-dudum-w-a

15.SC-PRES-thunder-PASS-PRES 


\author{
*Kuyawiwa isichotho. \\ ku-ya-wa-iw-a isichotho \\ 15.SC-PRES-fall-PASS-PRES hail
}

b. $\quad *$ There is being rained / thundered / hailed.

*Daar word gereën/gedonder/gehael. there is-being rained / thundered / hailed

\title{
4.3 Verbal versus adjectival passives
}

As pointed out in Section 2.3, English verbal and adjectival passives are homophonous, which gives rise to ambiguity. Afrikaans also displays this type of ambiguity, albeit to a lesser extent, with the passive auxiliaries is and was allowing both event and state readings (cf. Section 3.3). This type of ambiguity does not, however, occur in isiXhosa. According to Alcock, Rimba and Newton (2011:474), Bantu languages do not have "adjectival passives", i.e. passives with a state reading. In their acquisition studies of passive constructions in Sesotho, a Bantu language closely related to isiXhosa, Demuth et al. (2010:239-240) and Kline and Demuth (2010:223) state that passive constructions are (morpho-)syntactically distinct from adjectival constructions: in the formation of adjectives, a unique form of double adjectival agreement is used. This lack of ambiguity between passive and adjectival constructions is also found in isiXhosa, for the same reason. As is evident from the form of the passive verb in (60a) versus the form of the adjective in (60b) below, short passives are thus syntactically transparent, giving rise to an unambiguous event reading with an implied AGENT - a fact that has been cited in attempts to explain the generally early acquisition of passives in Sesotho (Demuth et al. 2010:239-240; Kline and Demuth 2010:223).
a. Isibane saphukiwe
(ngabafazi).
isi-bane si-aphuk-i(w)e
(ng-aba-fazi)
7-light 7.SC-break-PAST(PASS) (2.COP-2-women)
"The lamp was broken (by the women)"
b. Isibane esiphukileyo siwe emngangathweni.
isi-bane esi-phuk-ile-yo si-w-e e-mngangathu-eni
7-light 7.ADJ-break-PAST-ADJ 7.SC-fall-PAST LOC-floor-LOC
"The broken lamp fell on the floor"

The isiXhosa construction that most closely resembles an adjectival passive is the one containing a neuter form (referred to as the "neutro-passive" in Section 4.1), an example of which is supplied in (61) below. However, the neuter-containing construction differs morphologically, syntactically and semantically from the isiXhosa passive construction. Firstly, the neutro-passive morpheme forms -ek- and -akal-are distinct in form from the passive morpheme forms $-i w$ - and $-w$-. Secondly, the neutro-passive cannot, unlike long passives, take a copular noun phrase specifying an AGENT argument, as shown in (61) below. 


$\begin{array}{lll}\text { Le } & \text { ncwadi iyafundakala } & \text { (*ngabantwana). } \\ \text { Le } & \text { ncwadi i-ya-fund-akal-a } & \text { (*ng-aba-ntwana) }\end{array}$

9.DEM.this book 9.SC-PRES-read-NEUT-PRES $(* 2$. COP-2-children)

"This book is (in a state of being) readable/understandable (*by the children)"

Thirdly, the neutro-passive morpheme indicates that the verb stem denotes a state or the entering of a state (Du Plessis 1978:174). For instance, whereas - gobwa means "be bent (by an AGENT)", -gobeka means "be in a state of being bent". The isiXhosa neutro-passive construction can furthermore have the English "-able" reading: whereas -fundwa means "be read (by an AGENT)", -fundeka means "be readable", as illustrated in (61) above (Du Plessis 1978:174). Accordingly, the inherent differences in form and meaning between the passive morpheme and the neutro-passive morpheme rule out any possible ambiguity between an event and state reading in isiXhosa. ${ }^{38}$

\section{Acquisition of passive constructions in English, Afrikaans and isiXhosa}

Over the past four decades, much child language research has focused on the acquisition of the passive voice, motivated largely by the common delay in the acquisition of passive constructions across languages, both in terms of production and comprehension (Deen 2011:155). Overall late acquisition of the passive voice has been documented for many European languages - e.g. English at four to five years (cf. Maratsos, Fox, Becker and Chalkley 1985) and German at five years (cf. de Villiers 1984) - as well as Hebrew at eight years (cf. Berman 1985; Mills 1985). ${ }^{39}$ In the case of certain types of passive constructions, ages as advanced as nine and eleven years have been cited (Horgan 1978; Maratsos, Kuczaj, Fox, Becker and Chalkley 1979). For example, in a large-scale study by Horgan (1978) that employed 234 children aged between 2 and 14 years, instrumental non-reversible passives (e.g. The window was broken by the boys) were reportedly only produced spontaneously after the age of 9 years.

Whereas early research suggests that the passive voice is generally only fully acquired after the age of five years, more recent research indicates that this general estimate may be exaggerated, and that children perhaps have knowledge of the passive voice at a "significantly earlier" stage (Deen 2011:184). In some languages, knowledge of the passive appears as early as three years or younger (Alcock et al. 2011:459). Regardless of the exact age at which the

\footnotetext{
${ }^{38}$ According to Demuth et al. (2010:240), this is also the case in Sesotho, as neuter-containing constructions in this Bantu language differ morphologically, syntactically and semantically from passive constructions in several ways. First, the form of the neuter morpheme, i.e. either -eh- or -ahal-, is distinct from that of the passive morpheme $-w$ - or $-u w$-. Second, the neuter morpheme is infixed at the end of the verb stem before the perfective marker -il-, whereas the passive morpheme is infixed after -il-. Third, as in isiXhosa, the neuter-containing construction cannot include a copular noun phrase specifying an AGENT argument, unlike long passives. And fourth, whereas passive constructions have only an event reading, the neuter has an adjectival/state-like reading corresponding to the English interpretation expressed by the suffix "-able"; for instance, -ratwa means "be loved" and -rateha means "be lovable". As mentioned above, this is also one of the possible interpretations of the isiXhosa neutro-passive.

39 Note that the majority of studies do not provide a clear description of what exactly having "acquired" the passive entails, neither in terms of a minimum accuracy score on a passives test nor in terms of the skill type (for example comprehension versus production) that has purportedly been "acquired". As such, all references in this paper to specific ages at acquisition of the passive are quoted in line with the specific authors' conceptualisations (albeit sometimes vague or arbitrary) of what constitutes the completed acquisition of passive constructions.
} 
passive is acquired in specific languages, however, it may still be considered a typically laterdeveloping construction across languages (Southwood and Van Dulm 2012:48).

The primary focus in most of these studies has been on potential reasons for the delay in the acquisition of the passive voice, resulting in various theories to account for this general phenomenon. For a detailed overview and appraisal of such theories, cf. Crawford (2012) and Deen (2011); for some of the explanations offered for the comparatively early acquisition of the passive voice in some languages, cf. Alcock et al. (2011). An inquiry into the possible factors that may determine the comparatively late or early acquisition of the passive voice in various languages falls outside of the scope of the current paper. However, one attempt at explaining the late acquisition of passives, namely that of Seymour, Roeper and de Villiers (2005), will be touched on here. These researchers propose that passive constructions are typically late-acquired because of the following "hidden properties" that children must decipher: (i) there is always an AGENT argument, even if unspecified in the case of short passives; (ii) there is a difference between activity and consequence (i.e. the activity described in The paper is torn leads to the consequent state described in The paper is torn); and (iii) there is a difference between an agentive by-phrase and a prepositional by-phrase (i.e. The cars were driven by the men describes an action performed by the men, whereas The cars were driving by the men describes unspecified agents' actions of driving the cars past the men).

Not only typically developing children but also those with language impairment often find both the comprehension and production of passive constructions difficult (Southwood and Van Dulm 2012:49). Leonard, Wong, Deevy, Stokes and Fletcher (2006) highlight three possible reasons for this phenomenon. Firstly, passive sentences have an atypical word order in that the AGENT argument does not occur in the typical sentence-initial, preverbal position found in most active sentences, but occurs postverbally as part of a prepositional phrase. This means that a passive sentence cannot accurately be interpreted in a typical linear fashion, where the first noun phrase is considered representative of the AGENT argument and the second noun phrase representative of the THEME; such interpretations are, however, common among children with language impairment and among young typically developing children (Southwood and Van Dulm 2012:48). Secondly, active and passive sentences differ in terms of verb morphology: in the active sentence Christine baked the cheesecake, the verb baked expresses the past tense, but in the passive equivalent The cheesecake was baked by Christine, the past tense is expressed not by the main verb but by the auxiliary was, with the main verb now serving to express the passive voice (Southwood and Van Dulm 2012:49). A third reason offered by Leonard et al. (2006) in explanation of the trouble children with language impairment have with comprehending and producing passive constructions is the fact that the generation of a passive construction requires a relatively complex syntactic computation (cf. Leonard et al. 2006 for an accessible account of this computation).

As regards the different types of passive constructions, there appears to be a specific order of acquisition (Israel, Johnson and Brooks 2000). Both corpus studies and empirical studies that investigate the comprehension and production of passive constructions report that the acquisition of short passives precedes that of long passives, and that the acquisition of actional passives (i.e. passive constructions in which a physical action is expressed) precedes that of non-actional passives (i.e. passive constructions containing perceptual verbs or psychological verbs) (Alcock et al. 2011:461; Crawford 2012:5; Southwood and Van Dulm 
2012:47). ${ }^{40}$ The tendency among monolingual English learners to produce predominantly short as opposed to long passives has led researchers such as Horgan (1978) to suggest that these learners' short passives are in fact adjectival rather than verbal in nature. ${ }^{41}$ Recall that short passives allow both an adjectival and verbal reading in English, whereas long passives are unambiguously verbal. According to Alcock et al. (2011:459), true verbal passives seem to be fully acquired only by age six in the case of English monolinguals. If verbal passives prove more challenging to acquire for whatever reason, a preference for adjectival passives thus seems motivated, thereby explaining the predominance of short passives in early production.

Research suggests that in the case of monolingual English children specifically, learners generally take up to five years or longer to fully acquire the rules relating to passive constructions (Demuth et al. 2010:238). An early study by de Villiers and de Villiers (1973) tested English monolingual children's comprehension of the passive using an act-out methodology in which participants were given both active and passive sentence prompts to act out using toys. The oldest group of participants, aged between 32 and 37.5 months, exhibited a correct response to $87.8 \%$ of the active sentence prompts but to only $34.4 \%$ of the passive sentence prompts. In another early study, that by Baldie (1976), English monolingual children were shown to be capable of imitating passive constructions before five years, but only capable of comprehending them around the age of six years. The ability to produce this type of construction reportedly occurred as late as 7;6 in this sample of participants. According to Vasilyeva, Huttenlocher and Waterfall (2006:170), the fact that English monolinguals have been shown to be able to, at the age of four years, produce at least some full passives and, on grounds of their responses in conversations with adults, comprehend at least some such sentences, one may conclude, "on the basis of the analysis of spontaneous speech, that sometime around the age of 4 years the basic elements of the passive construction have been mastered" by monolingual English children.

As regards the acquisition of passive constructions by monolingual Afrikaans children, there is, to my knowledge, no available literature providing normative data indicating the age at which the passive voice is typically acquired. Some indication may, however, come from Dutch (the language from which Afrikaans is largely derived) - in this language, "hardly any" uses of the passive have been noted in the speech of monolingual children of pre-school age, i.e. of four years and younger, although there may be "precursors of the passive" at this age (Gillis and De Houwer 1998:28,35).

Let us now turn to the acquisition of passive constructions by monolingual child learners of the Southern Bantu language isiXhosa. The context-appropriate spontaneous use of the passive voice in the speech of children as young as three years has been reported for languages belonging to several different families, including (i) languages of the North

\footnotetext{
${ }^{40}$ Babyonyshev, Hart, and Grigorenko (2005) report a further distinction in the case of children with Specific Language Impairment (SLI), namely that the acquisition of actional passives is followed first by the acquisition of passives containing psychological verbs and then by that of passives containing perceptual verbs. They state, however, that typically-developing children's acquisition does not seem to be influenced by this fine distinction between verb types.

${ }^{41}$ Borer and Wexler (1987) suggest that the argument chain underlying verbal passives matures relatively late, causing adjectival passives to be acquired earlier in comparison. Their explanation is in line with a broader maturational account for the delayed acquisition of the passive voice, according to which the "cognitive architecture" of passive constructions matures later than that of other constructions (Alcock et al. 2011:460).
} 
American Inuit family (Allen and Crago 1996); (ii) various Mayan languages (Pye and Quixtan Poz 1988); (iii) Eastern Bantu languages, e.g. Kiswahili and Kigiriama (Alcock et al. 2011); and (iv), importantly, Southern Bantu languages, e.g. isiZulu (Suzman 1985, 1987, 1990) and Sesotho (Demuth 1989, 1990). With regard to verb types, non-actional passives (a typically rare construction in European languages) are reportedly produced at as early an age as 2;1 in the case of Kiswahili and Kigiriama (Alcock et al. 2011:459). Three-year-old monolingual Sesotho learners are also capable of matching both actional and non-actional reversible passives to pictures, and of successfully generalising passive syntax to novel verbs without priming, as reported in Demuth et al. (2010).

As regards the age at which the passive construction is acquired in isiXhosa specifically, there are no normative data available. However, isiXhosa, isiZulu and Sesotho are all closely related languages of the Southern Bantu family (Demuth et al. 2010:239). As such, the isiZulu and Sesotho data on the age of acquisition of the passive voice could provide a fairly reliable indication of what to expect in the case of isiXhosa, i.e. that monolingual children ought to be able to produce passives by the age of three years (the assumption being that the comprehension of passives would have preceded the development of productive skills).

As mentioned above, the focus of the present paper is not on the factors that may determine the comparatively late or early acquisition of the passive voice in various languages. However, apart from the factors suggested by Seymour et al. (2005) to underlie the overall later acquisition of passives across languages (cf. above), one other possible factor will be discussed in more detail here, namely the frequency of passive constructions in the input that a learner is exposed to. The focus on this specific factor is merited by the fact that it may explain cross-linguistic differences in age of acquisition of the passive, and by the amount of supporting literature involving Bantu languages. Studies have shown that in those languages in which passive constructions are produced relatively early, adult speech generally exhibits a high percentage of such constructions (Alcock et al. 2011:459). In contrast, in those languages where the passive voice is generally acquired late - such as English, German and Hebrew adult speech includes relatively few passives (cf. Gordon and Chafetz 1990; Pinker, Lebeaux and Frost 1987).

In their study of the Eastern Bantu languages Kiswahili and Kigiriama, Alcock et al. (2011:474) found two- and three-year-old children to be capable of using passive verbs "productively in appreciable quantities", provided those verbs were part of the input they received. The researchers (2011:474) argue that this phenomenon cannot be explained by any maturational account of the production of passives, and that a frequency account seems more plausible. Whilst they do not deny the possibility that the specific structure of passive constructions may also contribute to the early acquisition thereof in Eastern Bantu languages, they do maintain that the more often a given construction is heard in the input, the more likely it is to be acquired and, more importantly, to be acquired early (Alcock et al. 2011:473-474). Although Alcock et al. (2011:475) concede that more research on the production and comprehension of the passive voice in different languages is needed, they speculate that such research will most likely support their hypothesis that "high frequency in child-directed speech is a necessary, and likely sufficient, condition for early learning of the passive".

A high frequency of passive constructions in child-directed input has been noted for a number of Bantu languages, including Kiswahili (cf. Deen 2002 for data), Kigiriama (cf. Alcock et al. 
2011:464, in which adult native speakers report this), and Sesotho (cf. Kline and Demuth 2008; for corpus data from the CHILDES database, MacWhinney 2000). In the latter case, corpus data revealed Sesotho caregivers to use passive constructions ten times more frequently than what has been reported for English child-directed speech by Gordon and Chafetz (1990). Of the passive constructions occurring in the speech of the Sesotho caregivers, $60 \%$ were long passives - significantly more than the $4 \%$ reported for English. According to Demuth et al. (2010:240), this difference may be partially explained by the fact that, in Sesotho, logical subjects cannot be questioned in situ, but only from the by-phrase of a passive construction (e.g. The food is being cooked by whom?), or as part of a cleft/relative construction (e.g. It is who that is cooking (the) food?), the passive here being the more common, unmarked construction type. As subject questions constitute a large portion of childdirected speech, Sesotho children are exposed predominantly to long passives (Demuth et al. 2010:240). This is most likely also the case where isiXhosa children are concerned, given that isiXhosa is similar to Sesotho with respect to the manner in which logical subjects may be questioned. The isiXhosa example in (62a) below illustrates the ungrammaticality caused by questioning a logical subject in situ in this language without the use of a relative clause; whilst the other two examples illustrate the acceptability of doing so using a passive construction $(62 b)$ or a relative construction $(62 c)$.

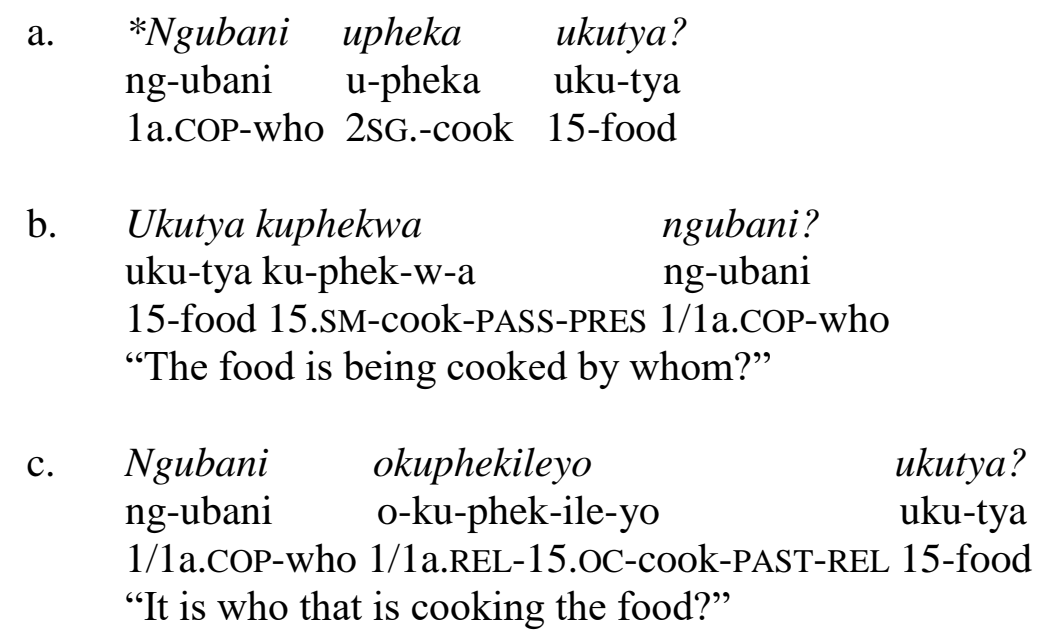

Kline and Demuth (2008) propose that the acquisition of the passive voice by Sesotho learners is aided by the high frequency of passive constructions in general and long passives specifically, because of the structural priming effect of the repeated occurrence of these constructions in the input. The latter serves to strengthen developing syntactic representations, so enabling learners to formulate abstract patterns on grounds of the individual examples they hear. Demuth et al. (2010:248), too, argue that the relatively high frequency of (mostly long) passives in the input from adult Sesotho speakers, along with the lack of morphological ambiguity between the passive and other constructions, "provides an ideal context for early learning of the passive". This is in all likelihood also the case as far as isiXhosa is concerned.

Studies such as those by Bencini and Valian (2008); Brooks and Tomasello (1999); Huttenlocher, Vasilyeva, Cymerman and Levine (2002); Huttenlocher, Vasilyeva and Shimpi (2004); and Savage, Lieven, Theakston and Tomasello (2003) have shown that monolingual English learners, when exposed in either a natural or experimental environment to an 
increased frequency of passive constructions, start producing such constructions at earlier ages than otherwise reported in the literature.

Frequency may furthermore account for differences in the ages at which the same learner acquires different types of passive constructions. As mentioned above, much recent data suggest that non-actional passives are acquired later than actional passives. Studies such as Alcock et al. (2011:474) and Gagarina (2007) show that this supposed differential difficulty relates to the amount of exposure a learner receives to the two types of passives at hand, i.e. the percentage of passive constructions of a certain type that a learner produces reflects the percentage of the input that this passive construction comprises. That monolingual English learners hear fewer non-actional than actional passives is suggested by Sudhalter and Braine (1985) and confirmed by Gordon and Chafetz (1990). As with passives in general, learners' production of non-actional passives specifically can also be experimentally enhanced by increasing their exposure to this type of construction, as shown by Maratsos et al. (1985) for English learners and Pye and Quixtan Poz (1988) for Quiche Mayan learners.

\section{Conclusion}

In conclusion, this paper provided a comprehensive comparative review of the grammar of passive constructions in three South African languages, i.e. South African English, Afrikaans and the Southern Bantu language isiXhosa. It furthermore discussed the comparatively late acquisition of passive constructions by monolingual learners of English versus monolingual learners of languages from certain other families, notably Bantu languages, in which these constructions reportedly occur more frequently. It is hoped that the information collated here may serve as a grammatical basis for future research into the acquisition of passives among monolingual but specifically also multilingual learners in African contexts, benchmark data on this phenomenon being as yet severely limited. For a report on an investigation into whether the relatively high frequency of passive constructions in the input that a developing trilingual receives in one of her three languages (isiXhosa) can enhance its acquisition in her other two typologically distinct languages (Afrikaans and English), the reader is referred to Potgieter $(2014 ;$ 2016).

\section{References}

Adger, D. 2003. Core syntax: A minimalist approach. Oxford: Oxford University Press.

Alcock, K. J., K. Rimba and C. R. J. C. Newton. 2011. Early production of the passive in two Eastern Bantu languages. First Language 32(4): 459-478. doi: 10.1177/0142723711419328

Alexiadou, A. 2005. A note on non-canonical passives: The case of the get-passive. In H. Broekhuis, N. Corver, R. Huybregts, U. Kleinhenz and J. Koster (eds.) Organizing grammar: Linguistic studies in honor of Henk van Riemsdijk. Berlin: Mouton de Gruyter. pp. 13-21.

Alexiadou, A. and E. Anagnostopoulou. 2007. Agent, causer and instrument PPs in Greek: Implications for verbal structure. Paper presented at Workshop on Greek Syntax and Semantics, MIT. 
Allen, S. E. and M. B. Crago. 1996. Early passive acquisition in Inuktitut. Journal of Child Language 23: 129-156. doi:10.1017/S0305000900010126

Babyonyshev, M., L. Hart and E. L. Grigorenko. 2005. The acquisition of passive constructions in Russian children with SLI. Paper presented at the 14th Annual Meeting of Formal Approaches to Slavic Linguistics, Princeton University.

Baldie, B. J. 1976. The acquisition of the passive voice. Journal of Child Language 3: 331349. doi:10.1017/S0305000900007224

Baratta, A. M. 2009. Revealing stance through passive voice. Journal of Pragmatics 41: 1406-1421. doi:10.1016/j.pragma.2008.09.010

Bencini, G. M. L. and V. V. Valian. 2008. Abstract sentence representations in 3-year-olds: Evidence from language production and comprehension. Journal of Memory and Language 59: 97-113. doi:10.1016/j.jml.2007.12.007

Berman, R. 1985. The acquisition of Hebrew. In D. Slobin (ed.) The crosslinguistic study of language acquisition (vol 1). Hillsdale, NJ: Lawrence Erlbaum. pp. 255-372.

Biberauer, T. 2002. Verb second in Afrikaans: Is this a unitary phenomenon? Stellenbosch Papers in Linguistics 34: 19-69. doi:10.5774/34-0-34

Biberauer, T. 2003. Verb Second (V2) in Afrikaans: A minimalist investigation of word-order variation. Doctoral dissertation. Cambridge, England: University of Cambridge.

Biberauer, T. and I. Roberts. 2006. The loss of residual "head-final" orders and remnant fronting in Late Middle English: Causes and consequences. In J. Hartmann and L. Molnárfi (eds.) Comparative studies in Germanic syntax. Amsterdam/Philadelphia: John Benjamins. pp. 263-297.

Borer, H. and K. Wexler. 1987. The maturation of syntax. In T. Roeper and E. Williams (eds.) Parameter setting. Dordrecht: D. Reidel Publishing Co. pp. 123-172.

Brooks, P. J. and M. Tomasello. 1999. Young children learn to produce passives with nonce verbs. Developmental Psychology 35(1): 29-44. doi:10.1037/0012-1649.35.1.29

Brownlow, O. S. 2011. Towards a unified analysis of the syntax and semantics of getconstructions. Doctoral dissertation. London, England: Queen Mary University of London.

Butler, J. and G. Tsoulas. 2006. Get-passives, raising, and control. Available online: http://www-users.york.ac.uk/ gt3/recent-mss/getpassives2.pdf.

Conradie, C. J. 1969. Die lydende vorm in Afrikaans. Master's thesis. Stellenbosch, South Africa: University of Stellenbosch.

Crawford, J. L. 2012. Developmental perspectives on the acquisition of the passive. Doctoral dissertation. Storrs, USA: University of Connecticut. 
Deen, K. U. 2002. The acquisition of Nairobi Swahili: The morphosyntax of inflectional prefixes and subjects. Doctoral dissertation. Los Angeles, USA: University of California.

Deen, K. U. 2011. The acquisition of the passive. In J. de Villiers and T. Roeper (eds.) Handbook of generative approaches to language acquisition. New York: Springer. pp. 155187.

Demuth, K. 1989. Maturation and the acquisition of the Sesotho passive. Language 65(1): 56-80. doi: $10.2307 / 414842$

Demuth, K. 1990. Subject, topic and the Sesotho passive. Journal of Child Language 17: 6784. doi:10.1017/S0305000900013106

Demuth, K., F. Moloi and M. Machobane. 2010. 3-Year-olds' comprehension, production, and generalization of Sesotho passives. Cognition 115: 238-51. doi: $\underline{10.1016 / j . c o g n i t i o n .2009 .12 .015}$

De Villiers, J. 1984. Learning the passive from models: Some contradictory data. Paper presented at the 9th annual Boston University Conference on Language Development, Boston, USA.

De Villiers, J. and P. de Villiers. 1973. Development of the use of word order in comprehension. Journal of Psycholinguistic Research 2: 331-341. doi: 10.1007/BF01067055

Doke, C. M. and S. M. Mofokeng. 1985. Textbook of Southern Sotho grammar. Cape Town: Longman.

Du Plessis, J. A. 1978. isiXhosa 4. Goodwood: Oudiovista.

Du Plessis, J. A. and M. Visser. 1992. Xhosa syntax (1st ed.). Pretoria: Via Afrika.

Embick, D. 2004. On the structure of resultative participles in English. Linguistic Inquiry 35(3): 355-392. doi:10.1162/0024389041402634

Gagarina, N. 2007. What happens when adults often use infinitives? In I. Gülzow and N. Gagarina (eds.) Frequency effects in language acquisition: Defining the limits of frequency as an explanatory concept. Berlin and New York: Mouton de Gruyter. pp. 205-233.

Gillis, S. and A. De Houwer. 1998. Dutch child language: An overview. In S. Gillis and A. De Houwer (eds.) The acquisition of Dutch. Amsterdam: John Benjamins. pp. 1-100.

Gordon, P. and J. Chafetz. 1990. Verb-based versus class-based accounts of actionality effects in children's comprehension of passives. Cognition 36(3): 227-254. doi: 10.1016/0010$\underline{0277(90) 90058-R}$

Haegeman, L. 1994. Introduction to Government and Binding Theory (2nd ed.). Oxford: Blackwell Publishers. 
Herbert, R. and R. Bailey. 2002. The Bantu languages: Sociohistorical perspectives. In R. Mesthrie (ed.) Language in South Africa. Cambridge: Cambridge University Press. pp. 50-78.

Hoekstra, T. 1984. Krijgen. In H. Bennis and W. Van Lessen Kloeke (eds.) Linguistics in the Netherlands. Dordrecht: Floris. pp. 65-72.

Horgan, D. 1978. The development of the full passive. Journal of Child Language 5: 65-80. doi:10.1017/S030500090000194X

Huttenlocher, J., M. Vasilyeva, E. Cymerman and S. Levine. 2002. Language input and child syntax. Cognitive Psychology 45(3): 337-374. doi:10.1016/S0010-0285(02)00500-5

Huttenlocher, J., M. Vasilyeva and P. Shimpi. 2004. Syntactic priming in young children. Journal of Memory and Language 50(2): 182-195. doi:10.1016/j.jml.2003.09.003

Israel, M., C. Johnson and P. J. Brooks. 2000. From states to events: The acquisition of English passive participles. Cognitive Linguistics 11(1-2): 103-129. $\underline{10.1515 / \operatorname{cog} 1.2001 .005}$

Kline, M. and K. Demuth. 2008. Structural priming, thematic roles, and the acquisition of the passive. Paper presented at the $3^{\text {rd }}$ Conference on Generative Approaches to Language Acquisition North America (GALANA 2008), University of Connecticut, Storrs, USA.

Kline, M. and K. Demuth. 2010. Factors facilitating implicit learning: The case of the Sesotho passive. Language Acquisition 17(4): 220-234. doi: 10.1080/10489223.2010.509268

Leonard, L. B., A. M.-Y. Wong, P. Deevy, S. F. Stokes and P. Fletcher. 2006. The production of passives by children with specific language impairment acquiring English or Cantonese. Applied Psycholinguistics 27(2): 267-299. doi:10.1017/S0142716406060280

Louw, J. A. and J. Jubase. 1963. Handboek van Xhosa. Johannesburg: Bonapers Beperk.

MacWhinney, B. 2000. The CHILDES project: Tools for analyzing talk (3rd ed.); The database (vol. 2). Mahwah, NJ: Lawrence Erlbaum.

Maratsos, M. P., D. Fox, J. Becker and M. A. Chalkley. 1985. Semantic restrictions on children's passives. Cognition 19: 167-191. doi:10.1016/0010-0277(85)90017-4

Maratsos, M. P., S. A. Kuczaj, D. Fox, J. A. Becker and M. A. Chalkley. 1979. Some empirical studies in the acquisition of transformational relations: Passives, negatives, and the past tense. In W. A. Collins (ed.) Children's language and communications. Hillsdale, NJ: Lawrence Erlbaum. pp. 1-45.

McArthur, T. (ed.). 1992. The Oxford companion to the English language. Oxford: Oxford University Press.

Mills, A. E. 1985. The acquisition of German. In D. Slobin (ed.) The cross-linguistic study of language acquisition (vol. 1). Hillsdale, NJ: Lawrence Erlbaum. pp. 141-254. 
Munnik, A. 2006. Learn Xhosa with Anne Munik (5th ed.). Pietermaritzburg: Shuter \& Shooter.

Oosthuizen, J. 2013. Obligatory reflexivity in Afrikaans: A minimalist approach. Doctoral dissertation. Stellenbosch, South Africa: Stellenbosch University.

Oosthuysen, J. C. J. 1958. Leer self Xhosa. Cape Town: Juta en Kie, Bpk.

Ouhalla, J. 1999. Transformational grammar: From principles and parameters to minimalism (2nd ed.). London: Arnold.

Pinker, S. 1989. Learnability and cognition: The acquisition of argument structure. Cambridge, MA: MIT Press.

Pinker, S., D. Lebeaux and L. Frost. 1987. Productivity and constraints in the acquisition of the passive. Cognition 26: 195-267. doi:10.1016/S0010-0277(87)80001-X

Ponelis, F. A. 1979. Afrikaanse sintaksis (1st ed.). Pretoria: J.L. van Schaik.

Ponelis, F. A. 1989. Sintaksis. In T. J. R. Botha, F. A. Ponelis, J. G. H. Combrink and F. F. Odendaal (eds.) Inleiding tot die Afrikaanse taalkunde (2nd ed.). Pretoria: Academica. pp. 255-357.

Potgieter, A. P. 2014. The role of input in the early trilingual acquisition of English, Afrikaans and isiXhosa. Doctoral dissertation. Stellenbosch, South Africa: Stellenbosch University.

Potgieter, A. P. 2016. Lexical and grammatical development in trilingual speakers of isiXhosa, English and Afrikaans. South African Journal of Communication Disorders, 63(2): 1-11. doi:10.4102/sajcd.v63i2.141

Pye, C. and P. Quixtan Poz. 1988. Precocious passives (and antipassives) in Quiche Mayan. Papers and Reports on Child Language Development 27: 71-80.

Quirk, R., S. Greenbaum, G. Leech, J. Swartvik and D. Crystal. 1985. A comprehensive grammar of the English language. London: Longman.

Radford, A. 2009. Analysing English sentences: A minimalist approach. Cambridge: Cambridge University Press.

Saule, N., C. K. Moropa, T. Zililo and N. P. Hadebe. 2007. IsiXhosa for beginners (Tutorial letter 501/3/2007). Pretoria: University of South Africa (Department of African Languages).

Savage, C., E. Lieven, A. Theakston and M. Tomasello. 2003. Testing the abstractness of children's linguistic representations: Lexical and structural priming of syntactic constructions in young children. Developmental Science 6(5): 557-567. doi: 10.1111/1467-7687.00312 
Seymour, H. N., T. W. Roeper and J. De Villiers. 2005. Diagnostic Evaluation of Language Variation - Norm Referenced (DELV-NR). San Antonio, TX: Pearson.

Southwood, F. and O. Van Dulm. 2012. Receptive and Expressive Activities for Language Therapy / Reseptiewe en Ekspressiewe Aktiwiteite vir Later-ontwikkelende Taalvaardighede (REALt): Passive booklet. Johannesburg: JvR Africa.

Stein, G. 1979. Studies in the function of the passive. Tubingen: Gunter Narr.

Sudhalter, V. and M. D. Braine. 1985. How does comprehension of passives develop? A comparison of actional and experiential verbs. Journal of Child Language 12(2): 455-470. doi:10.1017/S0305000900006541

Suzman, S. M. 1985. Learning the passive in Zulu. Papers and Reports on Child Language Development 24: 131-137.

Suzman, S. M. 1987. Passives and prototypes in Zulu children's speech. African Studies 46: 241-254. doi: 10.1080/00020188708707677

Suzman, S. M. 1990. Language acquisition in Zulu. Doctoral dissertation. Johannesburg, South Africa: University of Witwatersrand.

Svartvik, J. 1966. On voice in the English verb. The Hague: Mouton.

Taalkommissie van die Suid-Afrikaanse Akademie vir Wetenskap en Kuns. 2009. Afrikaanse woordelys en spelreëls (10th ed.). Cape Town: Pharos Woordeboeke.

Thatcher, K., H. Branigan, J. Mclean and A. Sorace. 2008. Children's early acquisition of the passive: Evidence from syntactic priming. In T. Marinis, A. Papangeli and V. Stojanovik (eds.) Proceedings of the Child Language Seminar 2007. Reading: University of Reading. pp. 195-205.

Vasilyeva, M., J. Huttenlocher and H. Waterfall. 2006. Effects of language intervention on syntactic skill levels in preschoolers. Developmental Psychology 42(1): 164-74. doi: $\underline{10.1037 / 0012-1649.42 .1 .164}$

Zeller, J. 2008. The subject marker in Bantu as an antifocus marker. Stellenbosch Papers in Linguistics 38: 221-254. doi:10.5774/38-0-31

Zwart, J.-W. 1997. Morphosyntax of verb movement: A minimalist approach to the syntax of Dutch. Dordrecht: Kluwer Academic Publishers. 